\title{
Methane emissions from global wetlands: An assessment of the uncertainty associated with various wetland extent data sets
}

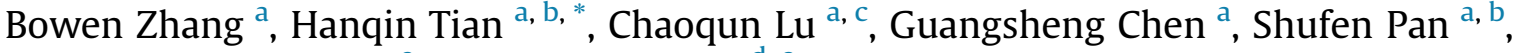 \\ Christopher Anderson a , Benjamin Poulter ${ }^{\mathrm{d}, \mathrm{e}}$ \\ a International Center for Climate and Global Change Research, School of Forestry and Wildlife Sciences, Auburn University, Auburn, AL 36849, USA \\ b State Key Laboratory of Urban and Regional Ecology, Research Center for Eco-Environmental Sciences, Chinese Academy of Sciences, Beijing 100085, China \\ ${ }^{c}$ Department of Ecology, Evolution, and Organismal Biology, Iowa State University, IA 50011, USA \\ d NASA Goddard Space Flight Center, Biospheric Sciences Laboratory, Greenbelt, MD 20771, USA \\ e Institute on Ecosystems and Department of Ecology, Montana State University, Bozeman, MT 59717, USA
}

\section{H I G H L I G H T S}

- Discrepancies in wetland extent are the major source of $\mathrm{CH}_{4}$ emission uncertainty.

- Tropics contribute the largest portion of estimated $\mathrm{CH}_{4}$ emissions from global wetland.

- Improved estimate of wetland area and $\mathrm{CH}_{4}$ emission in tropics are most critical.

- Global scale wetland data set with higher spatial and temporal resolution is desired.

\section{A R T I C L E I N F O}

\section{Article history:}

Received 27 February 2017

Received in revised form

28 June 2017

Accepted 2 July 2017

Available online 3 July 2017

\section{Keywords:}

Wetland

Methane

Uncertainty

Wetland data set

Tropics

\begin{abstract}
A B S T R A C T
A wide range of estimates on global wetland methane $\left(\mathrm{CH}_{4}\right)$ fluxes has been reported during the recent two decades. This gives rise to urgent needs to clarify and identify the uncertainty sources, and conclude a reconciled estimate for global $\mathrm{CH}_{4}$ fluxes from wetlands. Most estimates by using bottom-up approach rely on wetland data sets, but these data sets show largely inconsistent in terms of both wetland extent and spatiotemporal distribution. A quantitative assessment of uncertainties associated with these discrepancies among wetland data sets has not been well investigated yet. By comparing the five widely used global wetland data sets (GISS, GLWD, Kaplan, GIEMS and SWAMPS-GLWD), it this study, we found large differences in the wetland extent, ranging from 5.3 to 10.2 million $\mathrm{km}^{2}$, as well as their spatial and temporal distributions among the five data sets. These discrepancies in wetland data sets resulted in large bias in model-estimated global wetland $\mathrm{CH}_{4}$ emissions as simulated by using the Dynamic Land Ecosystem Model (DLEM). The model simulations indicated that the mean global wetland $\mathrm{CH}_{4}$ emissions during 2000-2007 were $177.2 \pm 49.7 \mathrm{Tg} \mathrm{CH}_{4} \mathrm{yr}^{-1}$, based on the five different data sets. The tropical regions contributed the largest portion of estimated $\mathrm{CH}_{4}$ emissions from global wetlands, but also had the largest discrepancy. Among six continents, the largest uncertainty was found in South America. Thus, the improved estimates of wetland extent and $\mathrm{CH}_{4}$ emissions in the tropical regions and South America would be a critical step toward an accurate estimate of global $\mathrm{CH}_{4}$ emissions. This uncertainty analysis also reveals an important need for our scientific community to generate a global scale wetland data set with higher spatial resolution and shorter time interval, by integrating multiple sources of field and satellite data with modeling approaches, for cross-scale extrapolation.
\end{abstract}

๑) 2017 Elsevier Ltd. All rights reserved.

\footnotetext{
* Corresponding author. International Center for Climate and Global Change Research, School of Forestry and Wildlife Sciences, Auburn University, Auburn, AL 36849, USA.
}

E-mail address: tianhan@auburn.edu (H. Tian).

\section{Introduction}

Carbon dioxide $\left(\mathrm{CO}_{2}\right)$, methane $\left(\mathrm{CH}_{4}\right)$ and nitrous oxide $\left(\mathrm{N}_{2} \mathrm{O}\right)$ account for more than $87 \%$ of the radioactive forcing (RF) due to long-lived greenhouse gases (LLGHGs) (WMO, 2015). Among them, 
methane ranks as the second largest RF (Ciais et al., 2013). The global warming potential (GWP) of $\mathrm{CH}_{4}$ is 28 times higher than that of $\mathrm{CO}_{2}$ at 100-year time horizon (Myhre et al., 2013). In 2014, the global abundance (as mole fractions) of $\mathrm{CH}_{4}$ had already reached $1833 \pm 1 \mathrm{ppb}$, an increase of $154 \%$ since pre-industrial time (WMO, 2015). The relative increase of $\mathrm{CH}_{4}$ is 1.8 and 2.1 times higher than that of $\mathrm{CO}_{2}$ and $\mathrm{N}_{2} \mathrm{O}$, respectively. The shorter lifetime ( $\sim 9$ years) and higher GWP make $\mathrm{CH}_{4}$ a good candidate to reduce the humaninduced climate warming (Dlugokencky et al., 2011; Tian et al., 2016). In addition, methane also determines the oxidizing capacity of troposphere by removing hydroxyl radical and subsequently changing the level of water vapor through $\mathrm{CH}_{4}$ oxidation and the climate influence of HFCs and HCFCs in the stratosphere (Ciais et al., 2013; Montzka et al., 2011). Thus, the change of atmospheric $\mathrm{CH}_{4}$ concentration could cause a quick response to the climate (Tian et al., 2016).

Among all natural and anthropogenic sources, wetlands are the single largest $\mathrm{CH}_{4}$ source and contribute $40 \%-50 \%$ of total $\mathrm{CH}_{4}$ emissions (Bohn et al., 2015; Kirschke et al., 2013; Saunois et al., 2016). Despite the crucial role of anthropogenic emission from a long-term perspective, $\mathrm{CH}_{4}$ emission from wetlands likely dominated the inter-annual variability of $\mathrm{CH}_{4}$ sources and determined the fluctuation of atmospheric $\mathrm{CH}_{4}$ in the recent two decades (Bousquet et al., 2006; Pison et al., 2013). Previous research has intensively examined $\mathrm{CH}_{4}$ emission from wetland ecosystems through bottom-up (BU: e.g., inventory, statistical extrapolation of local flux measurements, process-based modeling) and top-down (TD: atmospheric inversions) approaches (Kirschke et al., 2013; Tian et al., 2016). Furthermore, recent progress in deriving $\mathrm{CH}_{4}$ flux from field measurements, eddy-covariance and aircraft data allows for extensive observation-based evaluation. Nonetheless, wetlands are responsible for the largest absolute uncertainty from all the $\mathrm{CH}_{4}$ emission categories, with a range of $107 \mathrm{Tg} \mathrm{CH}_{4} \mathrm{yr}^{-1}$, approximately $49.3 \%$ of the global total estimate (Kirschke et al., 2013). Likewise, large discrepancies exist in spatial-temporal variation of estimated $\mathrm{CH}_{4}$ emission (Kirschke et al., 2013; Melton et al., 2013; Mitsch et al., 2013). One of the large uncertainties in estimates of $\mathrm{CH}_{4}$ emission comes from differences in wetland spatial extent being used (Bohn et al., 2015; Kirschke et al., 2013; Melton et al., 2013).

To determine the extent of global wetlands, terrestrial ecosystem models in general either simulate the extent through a hydrological module or use the wetland spatial data from inventory or remote sensing observations (Melton et al., 2013). However, model-simulated wetland extent tends to overestimate the wetland area and shows distinct patterns in spatial and temporal distribution compared to observed data sets (Melton et al., 2013; Stacke and Hagemann, 2012), which is partially attributed to the simplicity of model structure, parameterization, absence of several important processes and wetland determination schemes (Melton et al., 2013; Wania et al., 2013). Wetland extent data sets derived from inventory or satellite observations are broadly used in land ecosystem models to estimate $\mathrm{CH}_{4}$ emission and other biogeochemical processes at regional scale (Banger et al., 2015; Ito and Inatomi, 2012; Melton et al., 2013; Pison et al., 2013; Zhuang et al., 2015). Although identified, insufficient attention has been paid to the discrepancies among wetland data sets and estimates of $\mathrm{CH}_{4}$ emission caused thereby (Bridgham et al., 2013).

Here, we take one step toward unraveling the uncertainties caused by use of different wetland data sets. The Dynamic Land Ecosystem Model (DLEM), which has been widely used to estimate multiple greenhouse gas fluxes (Tian et al., 2015b), was chosen to quantify $\mathrm{CH}_{4}$ emission from global wetlands. The objectives of this study were to 1) examine the difference in the magnitude, spatial and temporal patterns of wetland distributions among the five data sets, 2) compare the differences in magnitude, spatial and temporal patterns of modeled $\mathrm{CH}_{4}$ fluxes as driven by the five wetland data sets, and 3) determine the uncertainties caused by wetland data sets and discuss potential strategies to reduce the uncertainties.

\section{Methodology}

\subsection{Wetland data sets}

In this study, we collected five wetland data sets, which were well recognized and used by different studies to estimate the $\mathrm{CH}_{4}$ emission and related biogeochemical processes in wetlands (Bergamaschi et al., 2007; Bloom et al., 2017; Bohn et al., 2015; Ito and Inatomi, 2012; Kirschke et al., 2013; Melton et al., 2013; Ringeval et al., 2011; Spahni et al., 2011; Zhu et al., 2015).

The first three data sets were all static in time. Matthews and Fung (1987) developed the first data set of the global distribution of wetlands in Goddard Institute for Space Studies (GISS) and classified wetlands into five types (forested bog, non-forested bog, forested swamp, non-forested swamp, and alluvial formations) with a spatial resolution of $1^{\circ} \times 1^{\circ}$. Lehner and Döll (2004) developed the Global Lakes and Wetlands Database (GLWD). GLWD provides a global coverage of maximum wetland extent, with a spatial resolution of 30'. Based on land cover types and land area fraction, nine wetland categories were classified in GLWD, including: (1) freshwater marsh, floodplain, (2) swamp forest, flooded forest, (3) coastal wetland, (4) pan, brackish/saline wetland, (5) bog, fen, mire, (6) intermittent wetland/lake, (7) $50-100 \%$ wetland, (8) 25-50\% wetland, and (9) wetland complex (0-25\% wetland) (Lehner and Döll, 2004). We used the mean fractions, i.e., $75 \%, 37.5 \%$, and $12.5 \%$, to represent grid scale wetland fractions for categories 7,8 , and 9, respectively. By using five major data sources (the Canadian peatland database (Tarnocai et al., 2000), the U. S. National Land Cover Dataset (Vogelmann et al., 2001), Global land Cover 2000 dataset (JRC, 2003), CORINE90 Land Cover dataset (ETCTE, 2000), and GLWD (Lehner and Döll, 2004)), Kaplan (2007) produced a global wetland map for 2003-2007, with a spatial resolution of $0.5^{\circ} \times 0.5^{\circ}$ (http://arve.unil.ch/pub/wetlands/index. html).

Based on a multi-satellite observation methodology, Papa et al. (2010) and Prigent et al. (2012) generated the Global Inundation Extent from Multi-Satellites (GIEMS) data set, which included both natural wetland and artificial wetland (referred to "paddy field"). GIEMS, for the first time, provided the global coverage and monthly change of inundation extent from 1993 to 2007, and was later used in the Wetland $\mathrm{CH}_{4}$ Intercomparison of Models Project (WETCHIMP) (Melton et al., 2013), in which the inland water bodies, like lakes and rivers were excluded. Recently, a global fractional surface water data set based on the Surface WAter Microwave Product Series Version 2.0 (SWAMPS) was developed to represent monthly land surface water fraction during 2000-2012 (Schroeder et al., 2015). Poulter et al. (2017) integrated GLWD with SWAMPS to develop a new global wetland data set (SWAMPS-GLWD), which has been used to quantify $\mathrm{CH}_{4}$ fluxes from wetlands at both regional (Bohn et al., 2015) and global scale (Bloom et al., 2017).

These five wetland data sets have all been widely used to represent global wetland area and distribution and to estimate wetland carbon and $\mathrm{CH}_{4}$ fluxes. Considering the large difference in wetland area, type, and spatial distribution patterns among the five data sets, the estimation of $\mathrm{CH}_{4}$ fluxes based on these data sets could differ significantly. Therefore, large uncertainty in global $\mathrm{CH}_{4}$ fluxes could arise from the choosing of wetland data sets. In our study, we transformed these data sets to the same spatial resolution of $0.5^{\circ} \times 0.5^{\circ}$ for driving an ecosystem model. When comparing the wetland extent of dynamic wetland data sets with static wetland 
data sets, we first calculated the maximum occurrence of wetland area in each year and get the 15-year and 13-year averages in GIEMS and SWAMPS-GLWD to represent their wetland extents, respectively.

\subsection{Dynamic Land Ecosystem Model (DLEM)}

The DLEM is comprised of five major components: (1) biophysics, (2) plant physiology, (3) soil biogeochemistry, (4) vegetation dynamics, and (5) land use, land management practices and disturbance. The DLEM can make daily, spatially-explicit estimations of the exchange of water, carbon and nitrogen fluxes between land and the atmosphere and at the land-ocean interface. The major components and related processes have been well described in previous publications (Lu and Tian, 2013; Ren et al., 2011; Tian et al., 2010a, 2012, 2015b, 2015c).

In the DLEM, the $\mathrm{CH}_{4}$-related processes are assumed to occur in the top $50 \mathrm{~cm}$ of soil. The DLEM only accounts for $\mathrm{CH}_{4}$ produced from dissolved organic carbon (DOC), which comes from the decomposition of vegetative litter and soil organic matter, and the byproduct of gross primary production (GPP). In the DLEM, the net $\mathrm{CH}_{4}$ fluxes were collectively determined by $\mathrm{CH}_{4}$ production, oxidation, and transport from soil to the atmosphere.

Methane production is calculated using the Michaelis-Menten equations, and is a function of DOC, soil $\mathrm{pH}$, temperature, and soil moisture content. Methane oxidation occurs through three pathways, including atmospheric $\mathrm{CH}_{4}$ oxidation (refers to the oxidation of $\mathrm{CH}_{4}$ transported from the atmosphere), $\mathrm{CH}_{4}$ oxidation in the soil pore water, and $\mathrm{CH}_{4}$ oxidation during plant-mediated transport. Methane is assumed to be transported from soil pore to the atmosphere via ebullition, diffusion, and plant-mediated transport. More detailed information about the DLEM simulation of $\mathrm{CH}_{4}$ fluxes was described in Tian et al. (2010b).

The $\mathrm{CH}_{4}$ module in the DLEM has already been extensively validated and applied at various spatial scales, including site, regional, and global scales (Banger et al., 2015; Lu and Tian, 2013; Pan et al., 2014, 2015; Ren et al., 2011; Tian et al., 2010b, 2015b; Xu and Tian, 2012). The DLEM's performance in simulating daily and annual $\mathrm{CH}_{4}$ fluxes has been evaluated against estimates from field observational data, inventory studies, other process-based and inverse models (Banger et al., 2015; Bohn et al., 2015; Tian et al., 2011; Xu et al., 2010). These evaluations have indicated that the DLEM can generally capture the magnitude and temporal variation of $\mathrm{CH}_{4}$ fluxes.

\subsection{Other model input data}

To run the DLEM, geo-referenced data with spatial resolution of $0.5^{\circ}$ are grouped into two broad categories, which includes (1) dynamic data at daily time-step (e.g., climate data -maximum, minimum, and mean air temperature, precipitation, relative humidity, and shortwave solar radiation, and AOT40 $\mathrm{O}_{3}$ index), and at annual time-step (e.g., data sets of atmospheric chemical components - atmospheric $\mathrm{CO}_{2}$ concentration, and nitrogen deposition; data sets of land use and land management practices), and (2) one phase static data (e.g., data set of soil properties - soil texture, soil $\mathrm{pH}$, and soil bulk density; and other ancillary data, such as river network and topographic data). More specifically, daily climate data was derived from CRUNCEP 6-hourly climate data sets (http:// forge.ipsl.jussieu.fr/orchidee/wiki/Documentation/Forcings). Atmospheric $\mathrm{CO}_{2}$ concentration was obtained from Ice core and NOAA observations (https://www.esrl.noaa.gov/gmd/ccgg/trends/global. html). Atmospheric ozone index (AOT40- Accumulated Ozone exposure over a Threshold of $40 \mathrm{ppb}$ ) was used to represent the influences of tropospheric ozone exposure on vegetation photosynthesis (Felzer et al., 2005; Ren et al., 2007). The AOT40 data was obtained from Felzer et al. (2005). Atmospheric nitrogen deposition data was interpolated based on the three time periods (1860, 1993 and 2050) of global nitrogen deposition maps (Dentener et al., 2006). The interpolation methods have been described in Tian et al. (2015a) and Wei et al. (2014). The georeferenced information for the soil physical properties was derived from FAO/IIASA/ISRIC/ISSCAS/JRC (2012). The land use and land cover data were collected from HYDE 3.1 (Klein Goldewijk et al., 2011). More detailed information about these data sets and the analysis of spatial and temporal patterns were shown in Zhang et al. (2016).

\subsection{Model experimental design}

To address the uncertainties of global and regional-scale estimations of $\mathrm{CH}_{4}$ emission due to different wetland extent data, we conducted ten simulations in total (using each wetland data set to run two simulations). We used averaged climate data from 1901 to 1930 and kept all other input variables constant at the level in 1900 to drive the model until DLEM reach equilibrium state and get the initial condition in 1900. Then, the model was run another 900 years for the spin-up with de-trended climate data from 1901 to 2012, which was to smooth the transition between equilibrium and the transient run. In the transient simulations, we considered multiple environmental changes during 1901-2012 to estimate $\mathrm{CH}_{4}$ emission from wetlands. For one-phase static wetland data sets (GISS, GLWD, and Kaplan), we assumed the wetland extent didn't change over time. For time-series dynamic wetland data sets (GIEMS and SWAMPS-GLWD), we extracted the seasonal trend from long-term mean wetland extent and applied it to the study period beyond the observation period.

\subsection{Analysis and statistical methods}

The period 2000-2007 (the overlapped period from the dynamic wetland data sets) was chosen to quantify the uncertainties in the estimated $\mathrm{CH}_{4}$ emission by using different wetland data sets. When comparing the inter-annual variation of estimated $\mathrm{CH}_{4}$ emission from different data sets, we subtracted the averaged $\mathrm{CH}_{4}$ emission ( $F_{\text {avg_2000-2007 }}$ during the overlapped period (2000-2007) from estimated $\mathrm{CH}_{4}$ emission from each year $\left(\mathrm{F}_{\mathrm{year}}\right)$ to determine the anomalous fluxes ( $\left.F_{\text {year }}-\mathrm{F}_{\mathrm{avg} \_2000-2007}\right)$. The crossdata standard deviation for wetland extent or estimated $\mathrm{CH}_{4}$ emission refers to the standard deviation that is derived from different wetland data sets, either in depicting wetland extent or estimating wetland $\mathrm{CH}_{4}$ emission $\left(S D=\sqrt{\frac{\sum\left(F_{i}-F_{\text {avg }}\right)}{4}}, i\right.$ indicates different wetland data sets).

\section{Results}

\subsection{Wetland area, extent and uncertainties}

Our results showed that the mean global wetland area of five wetland data sets was $7.8 \pm 2.2$ (Avg. \pm 1 std. Dev.) million $\mathrm{km}^{2}$ and varied from 5.3 million $\mathrm{km}^{2}$ (GISS) to 10.2 million $\mathrm{km}^{2}$ (SWAMPSGLWD). All data sets showed that the low latitude ( $\left.\mathrm{LL}, 30^{\circ} \mathrm{S}-30^{\circ} \mathrm{N}\right)$ had the largest wetland area $\left(3.4 \pm 1.1\right.$ million $\mathrm{km}^{2}$, Fig. $\left.1 \mathrm{a}\right)$, which accounted for about $43 \pm 4 \%$ of the total wetland area. However, the wetland area in the LL varied from $\sim 1.9$ million $\mathrm{km}^{2}$ in GISS (37\% of the global wetland area) to 4.3 million $\mathrm{km}^{2}$ in GIEMS (47\% of the global wetland area). The middle latitude (ML, $30^{\circ}-60^{\circ} \mathrm{N}$ and $\mathrm{S}$ ) accounted for around $36 \pm 1 \%$ of the global wetland area $(\sim 2.8 \pm 0.9$ million $\mathrm{km}^{2}$ ). The estimated wetland area from GISS and Kaplan 

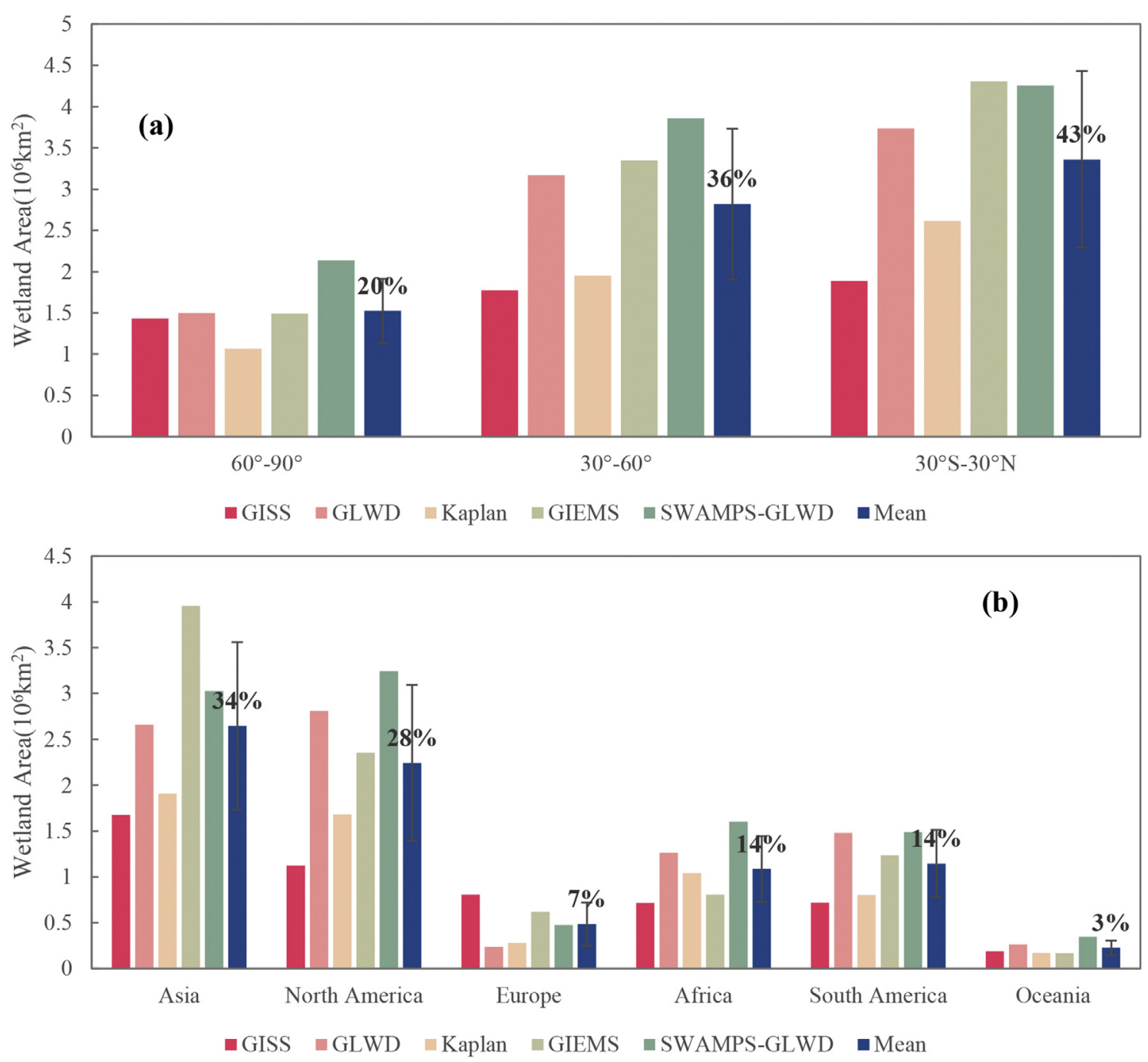

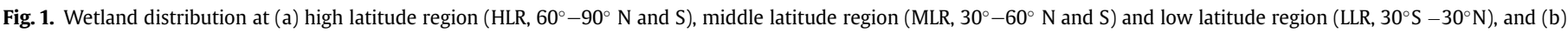

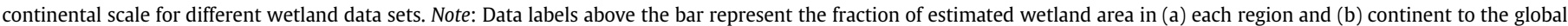
wetland area.

matched well (1.8-2.0 million $\mathrm{km}^{2}$ ), which was much lower than the estimate from GLWD, GIEMS (3.2-3.4 million $\mathrm{km}^{2}$ ) and SWAMPS-GLWD (3.9 million $\mathrm{km}^{2}$ ). The high latitude ( $\mathrm{HL}, 60^{\circ}-90^{\circ}$ $\mathrm{N}$ and S) accounted for $20 \pm 5 \%$ of the global total wetland area. GISS, GLWD, and GIEMS all suggested that the wetland area was around 1.4-1.5 million $\mathrm{km}^{2}$; Kaplan had the smallest wetland area $\left(\sim 1.1\right.$ million $\left.\mathrm{km}^{2}\right)$ and SWAMPS-GLWD had the largest ( $\sim 2.1$ million $\mathrm{km}^{2}$ ). From the latitudinal distribution, all the data set except GIEMS showed a peak wetland distribution around $60^{\circ} \mathrm{N}-66^{\circ} \mathrm{N}$, where large areas of peatland distributed (Fig. 1), but GIEMS showed large wetland extent in $20^{\circ} \mathrm{N}-33^{\circ} \mathrm{N}$ owing to the inclusion of rice paddy land.

At the continental scale, all data sets except GIEMS had about one-third of wetland area in Asia, while GIEMS had $43 \%$ of wetland area due to its inclusions of rice paddy land (Fig. 1b). Larger discrepancies in wetland extent were found in northeast China, and India. North America accounted for about $28 \pm 8 \%$ of the global wetland area, which was two times higher than that in Africa (14 $\pm 3 \%)$ and South America $(14 \pm 1 \%)$. Europe and Oceania together shared approximately $10 \%$ of the global wetland area. There was a large difference in wetland extent among the five data sets in Northern Europe, the Hudson Bay Lowland (HBL) and the
West Siberian Lowland (WSL) (Fig. 2b).

The temporal variation in wetland extent can be observed from dynamic wetland data sets (GIEMS and SWAMPS-GLWD). For both data sets, a decreasing trend was found in South America. GIEMS showed a decreasing trend in Canada, the WSL, India and East China in summer (June August, JJA) during 1993-2007 (Fig. 3). SWAMPS-GLWD showed an apparent increase at the northern high latitude, especially in the HBL and the WSL in spring (March May, MAM), summer and autumn (September $\sim$ November, SON) during 2000-2012 (Fig. 3). The wetland extent from SWAMPS-GLWD declined in Alaska, Alberta, and Northwest Territories of Canada in summer and autumn. The wetland extent in swamp forest and floodplain extent in South America showed a decreasing trend for all seasons during 2000-2012. The largest decline of wetland extent from GIEM $\left(\sim 18,060 \mathrm{~km}^{2} / \mathrm{yr}\right)$ was found at the $30^{\circ} \mathrm{N}-60^{\circ} \mathrm{N}$ zone in summer. The wetland extent in LL showed a decreasing trend in four seasons, with a rate ranging from $13,011 \mathrm{~km}^{2} / \mathrm{yr}$ in spring to $16,392 \mathrm{~km}^{2} / \mathrm{yr}$ in autumn. SWAMPS-GLWD data indicated a significant reduction of wetland area in LL, with a rate ranging from $7177 \mathrm{~km}^{2} / \mathrm{yr}$ in spring to $17,846 \mathrm{~km}^{2} / \mathrm{yr}$ in autumn during 2000-2012. On the contrary, there was an increasing trend at the $30^{\circ} \mathrm{N}-90^{\circ} \mathrm{N}$ zone in winter (December $\sim$ February, DJF), spring and 

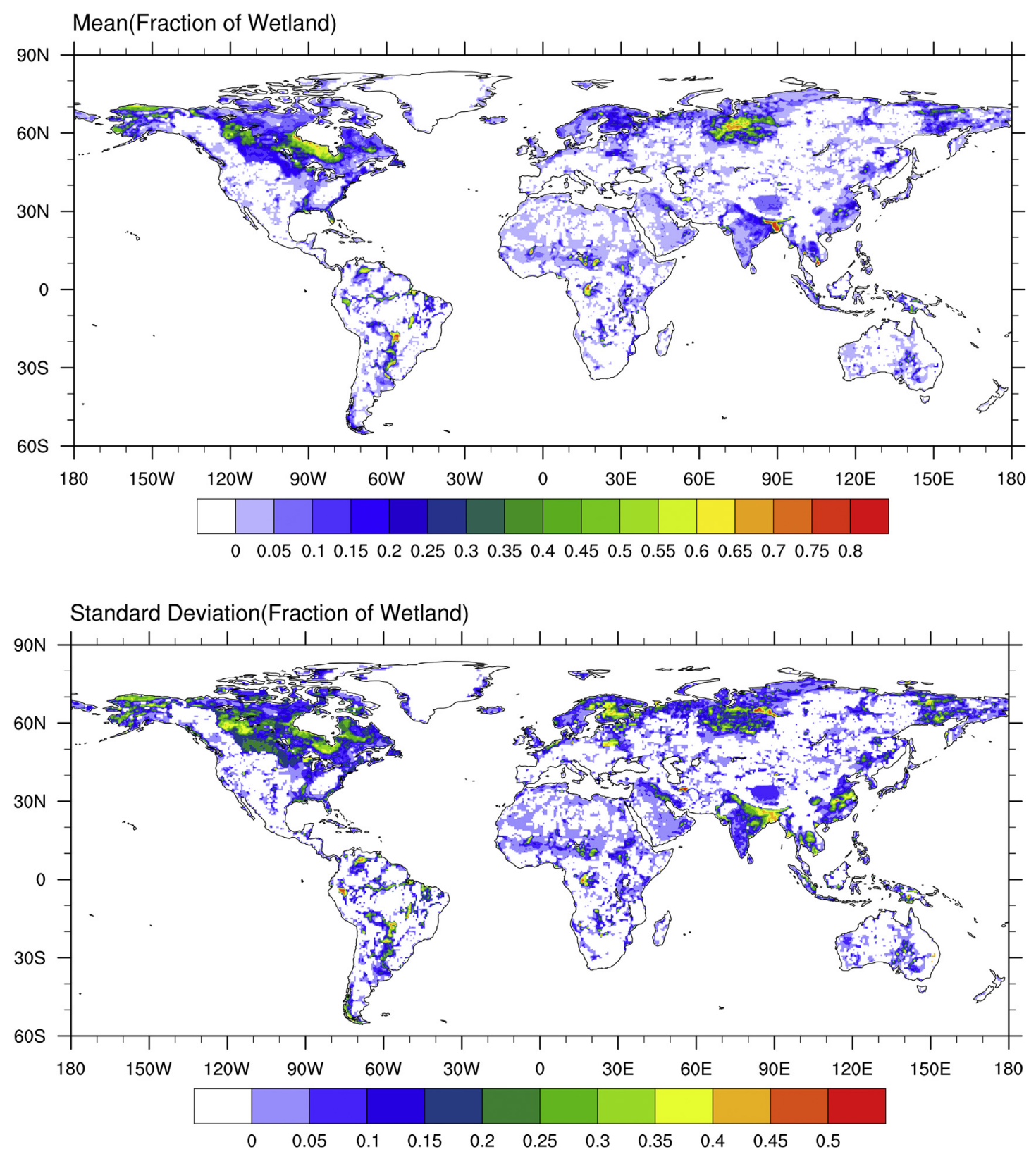

Fig. 2. The spatial distribution of mean wetland fraction (top) and standard deviation (bottom) based on the 5 wetland data sets.

autumn. For the intra-annual variations, both data sets indicated that wetland area reached the maximum in August, and minimum in December.

\subsection{Methane emission magnitudes and uncertainties}

We evaluate the uncertainty coming from wetland extent and it turns out that the simulated $\mathrm{CH}_{4}$ emissions from global wetlands were $177.2 \pm 49.7 \mathrm{Tg} \mathrm{CH}_{4} \mathrm{yr}^{-1}$, with the maximum emissions using GLWD data set $\left(263.4 \mathrm{Tg} \mathrm{CH}_{4} \mathrm{yr}^{-1}\right.$ ) and the minimum using GIEMS data set (141.3 $\mathrm{Tg} \mathrm{CH}_{4} \mathrm{yr}^{-1}$ ) (Fig. 4). At the regional scale, LL had the largest portion $(\sim 2 \pm 7 \%)$ of estimated $\mathrm{CH}_{4}$ emission and the largest uncertainty $\left(128.3 \pm 38.5 \mathrm{Tg} \mathrm{CH}_{4} \mathrm{yr}^{-1}\right)$, ranging from $91.0 \mathrm{Tg}$ $\mathrm{CH}_{4} \mathrm{yr}^{-1}$ (GIEMS) to $187.9 \mathrm{Tg} \mathrm{CH}_{4} \mathrm{yr}^{-1}$ (GLWD). ML and $\mathrm{HL}$ contributed $\sim 25 \pm 6 \%$ and $\sim 9 \pm 2 \%$ of the total emissions, respectively. The mean $\mathrm{CH}_{4}$ emission in ML was $43.8 \pm 13.6 \mathrm{Tg} \mathrm{CH}_{4} \mathrm{yr}^{-1}$, with lower estimation using GISS (31.6 $\mathrm{Tg} \mathrm{CH}_{4} \mathrm{yr}^{-1}$ ) and Kaplan
(32.2 $\mathrm{Tg} \mathrm{CH}_{4} \mathrm{yr}^{-1}$ ) data sets and higher estimation using SWAMPSGLWD (56.9 $\mathrm{Tg} \mathrm{CH}_{4} \mathrm{yr}^{-1}$ ) and GLWD (59.9 $\mathrm{Tg} \mathrm{CH}_{4} \mathrm{yr}^{-1}$ ) data sets. For the $\mathrm{HL}, \mathrm{CH}_{4}$ emission was $14.8 \pm 3.4 \mathrm{Tg} \mathrm{CH}_{4} \mathrm{yr}^{-1}$, ranging from 11.8 $\mathrm{Tg} \mathrm{CH}_{4} \mathrm{yr}^{-1}$ (Kaplan and GIEMS) to $20.0 \mathrm{Tg} \mathrm{CH}_{4} \mathrm{yr}^{-1}$ (SWAMPSGLWD).

Among the six continents, South America contributed the largest portion of estimated wetland $\mathrm{CH}_{4}$ emission $(\sim 53.5 \pm 23.2 \mathrm{Tg}$ $\mathrm{CH}_{4} \mathrm{yr}^{-1}$ ) despite it only covered $14 \%$ of global wetland area, followed by Asia $\left(\sim 47.4 \pm 11.3 \mathrm{Tg} \mathrm{CH}_{4} \mathrm{yr}^{-1}\right)$, Africa $\left(\sim 34.9 \pm 13.8 \mathrm{Tg} \mathrm{CH}_{4}\right.$ $\left.\mathrm{yr}^{-1}\right)$, and North America $\left(\sim 30.2 \pm 13.3 \mathrm{Tg} \mathrm{CH}_{4} \mathrm{yr}^{-1}\right)$ (Table $1 \&$ Fig. 4). Europe and Oceania contributed the least portions of the $\mathrm{CH}_{4}$ emission, which was $6.4 \pm 3.1$ and $4.8 \pm 1.6 \mathrm{Tg} \mathrm{CH} \mathrm{yr}^{-1}$, respectively.

The largest uncertainties in $\mathrm{CH}_{4}$ emission were found in South America and Africa. In South America, the large uncertainty was mainly due to the high estimation using GLWD data set $(\sim 93.0 \mathrm{Tg}$ $\mathrm{CH}_{4} \mathrm{yr}^{-1}$ ), which was about two times larger than those using other 


\section{Trend of Wetland Fraction (1993-2007)}

(a)

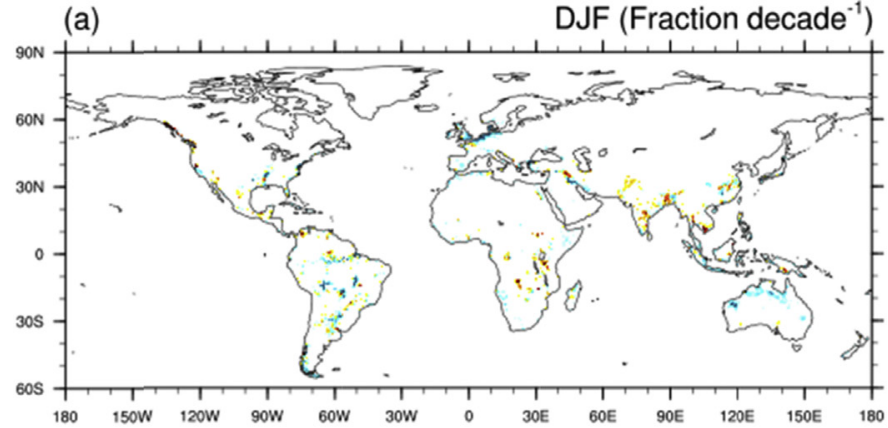

(c)

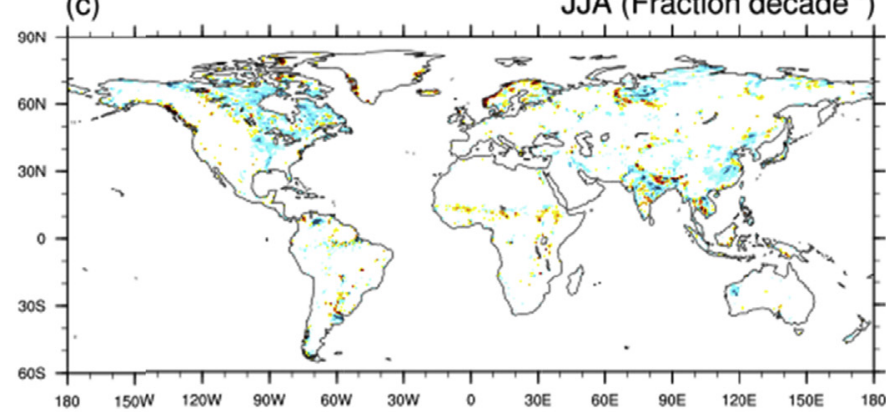

(b)

(b)

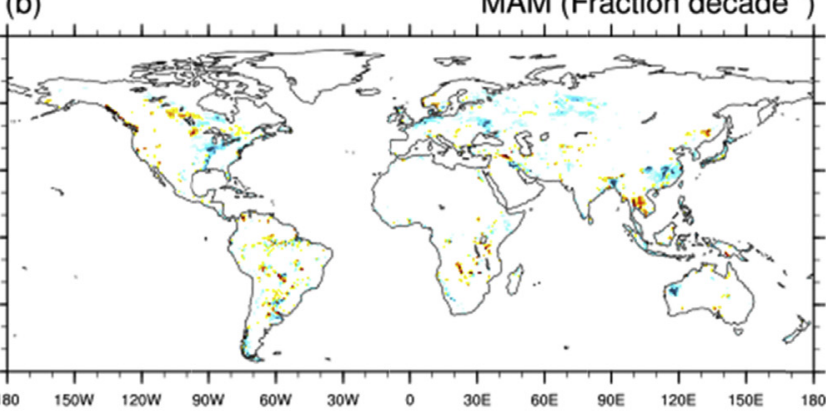

(d) SON (Fraction decade ${ }^{-1}$ )

$\begin{array}{lllllllllll}-0.1 & -0.08 & -0.06 & -0.04 & -0.02 & 0 & 0.02 & 0.04 & 0.06 & 0.08 & 0.1\end{array}$

\section{Trend of Wetland Fraction (2000-2012)}

(a)

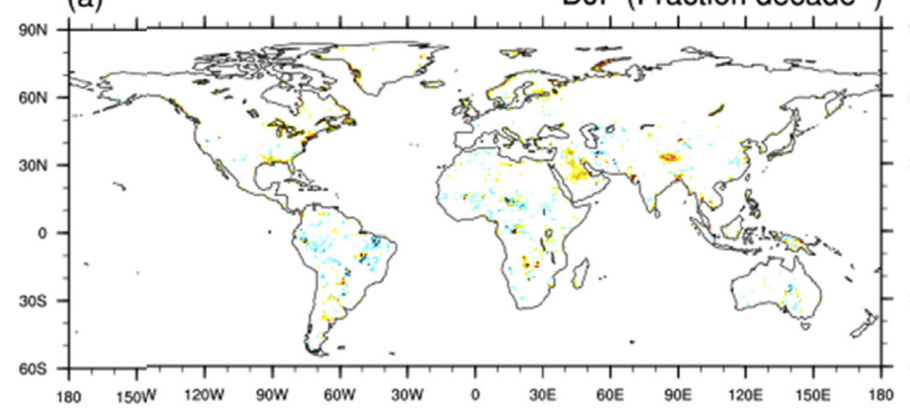

(b)
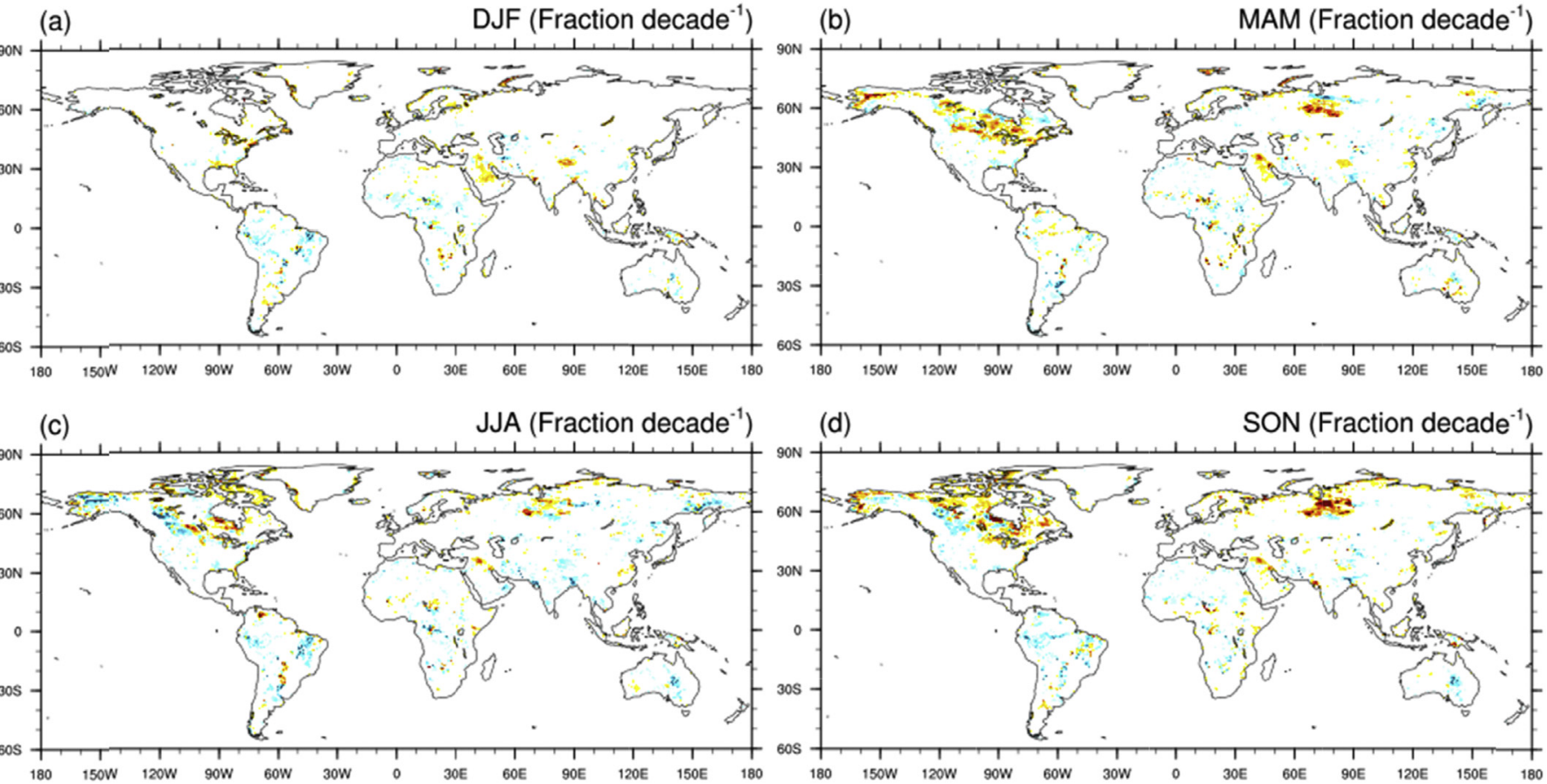

(d)

SON (Fraction decade ${ }^{-1}$ )

$$
\begin{array}{lllllllllll}
-0.1 & -0.08 & -0.06 & -0.04 & -0.02 & 0 & 0.02 & 0.04 & 0.06 & 0.08 & 0.1
\end{array}
$$

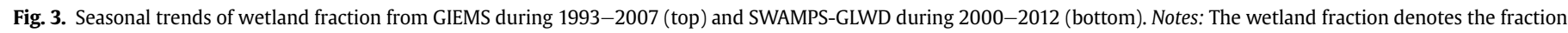

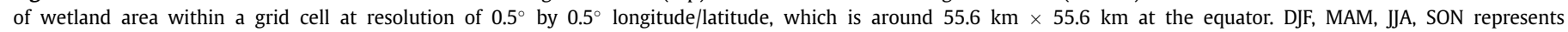
December $\sim$ February (winter), March $\sim$ May (spring), June $\sim$ August (summer), and September $\sim$ November (autumn), respectively. 
Global

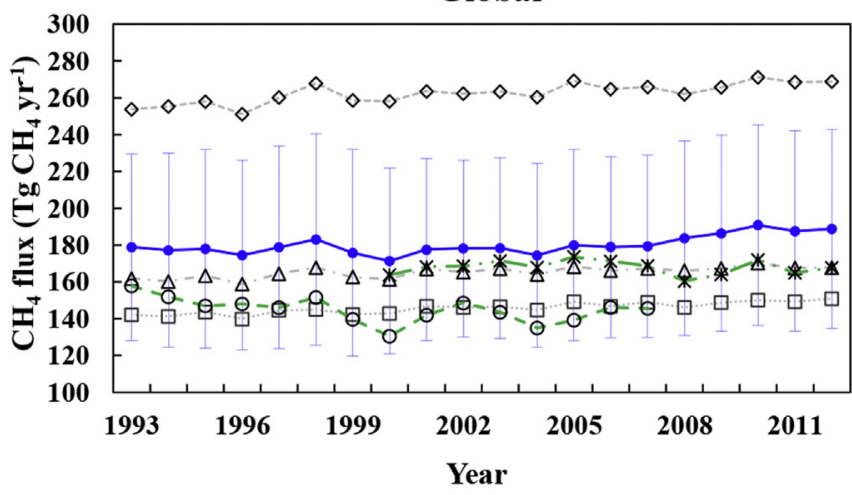

North America

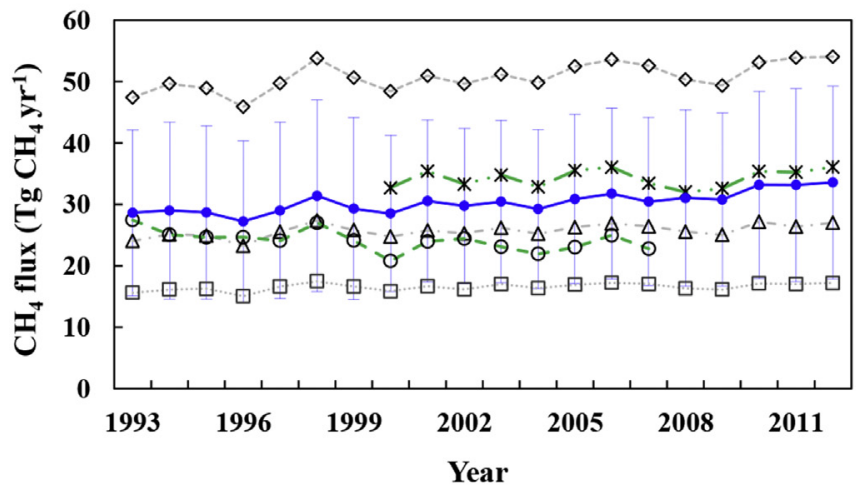

Africa

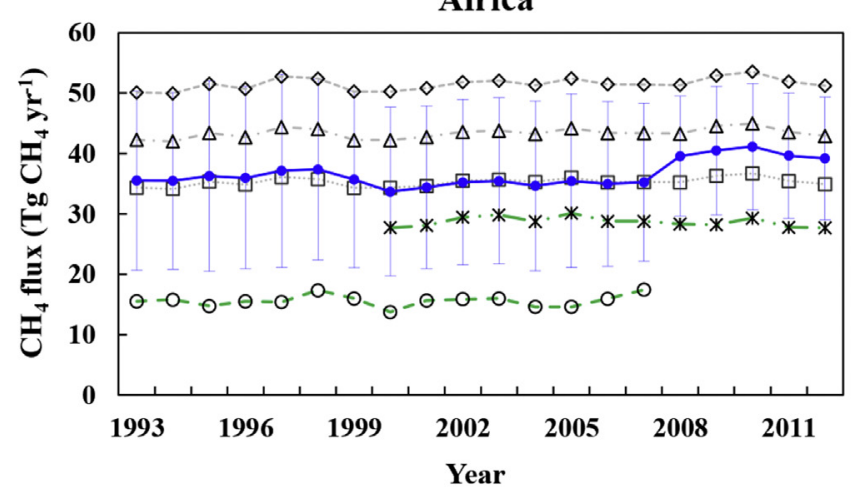

Oceania

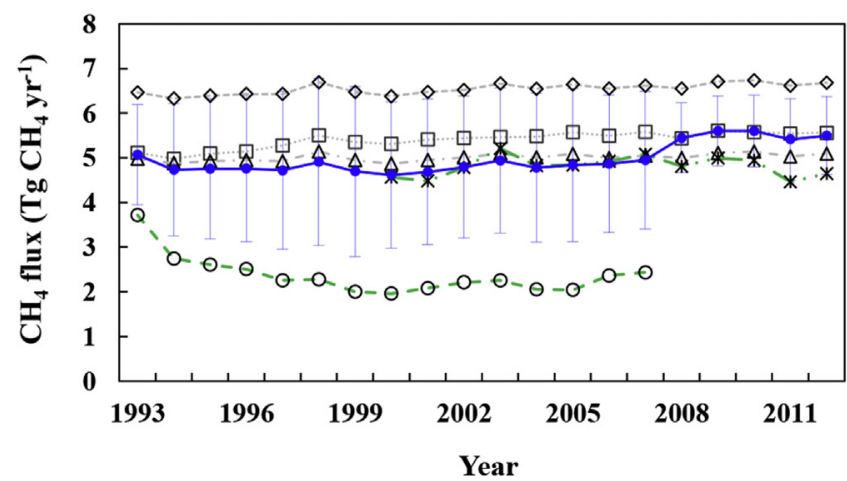

Asia

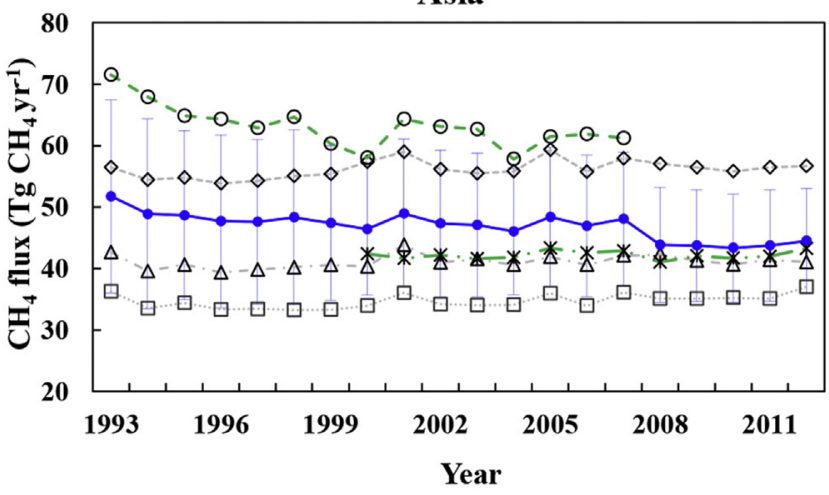

Europe
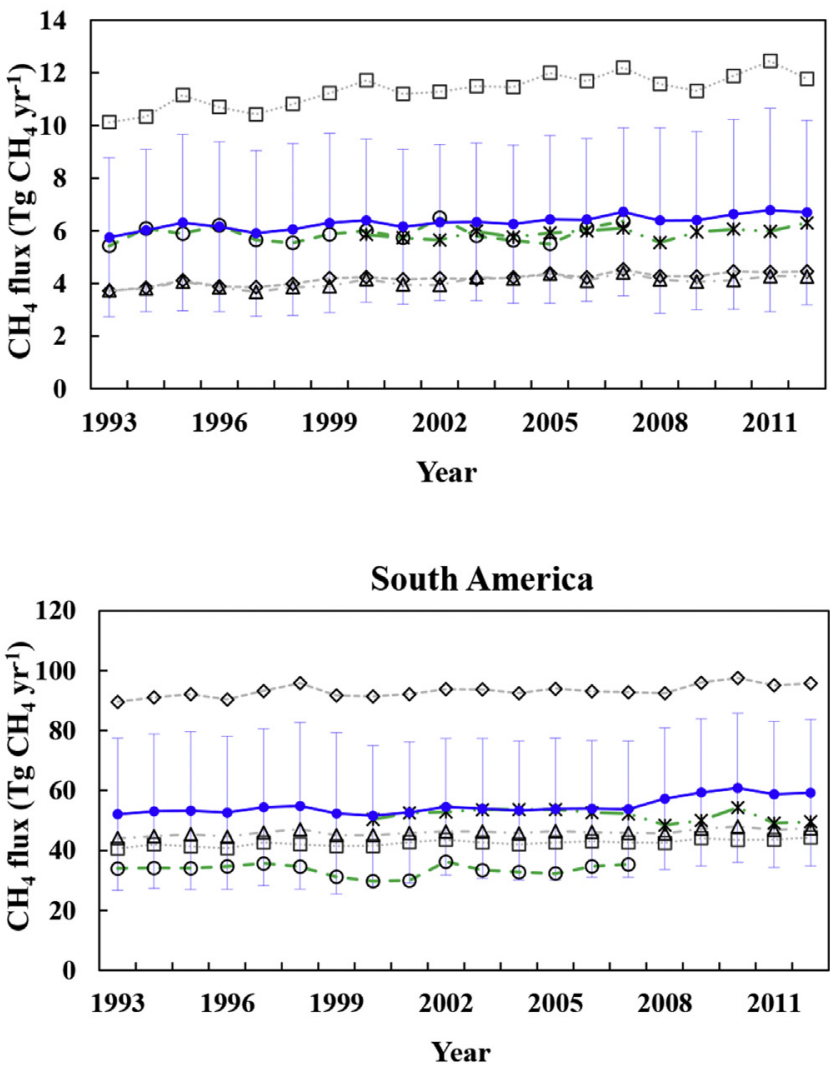

Fig. 4. Wetland $\mathrm{CH}_{4}$ emission at global and continental scales using different wetland data sets. 
Table 1

Estimated wetland $\mathrm{CH}_{4}$ emission during 2000-2007 at global and continental scales using different wetland data sets.

\begin{tabular}{|c|c|c|c|c|c|c|}
\hline $\mathrm{Tg} \mathrm{CH}_{4} \mathrm{yr}^{-1}$ & GISS & GLWD & Kaplan & GIEMS & SWAMPS-GLWD & Mean \\
\hline Global & 146.5 & 263.4 & 165.9 & 141.3 & 169.1 & $177.2 \pm 49.7$ \\
\hline Asia & 34.8 & 57.1 & 41.5 & 61.3 & 42.3 & $47.4 \pm 11.3$ \\
\hline North America & 16.7 & 51.1 & 25.9 & 23.1 & 34.3 & $30.2 \pm 13.3$ \\
\hline Europe & 11.6 & 4.3 & 4.2 & 6.0 & 5.9 & $6.4 \pm 3.1$ \\
\hline Africa & 35.2 & 51.5 & 43.3 & 15.5 & 28.9 & $34.9 \pm 13.8$ \\
\hline South America & 42.7 & 93.0 & 46.0 & 33.1 & 52.7 & $53.5 \pm 23.2$ \\
\hline Oceania & 5.5 & 6.5 & 5.0 & 2.2 & 4.8 & $4.8 \pm 1.6$ \\
\hline
\end{tabular}

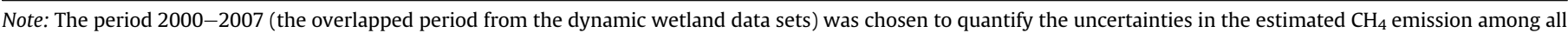
wetland data sets.

data sets (33.1 $\mathrm{Tg} \mathrm{CH}_{4} \mathrm{yr}^{-1}$ from GIEMS 52.7 $\mathrm{Tg} \mathrm{CH}_{4} \mathrm{yr}^{-1}$ from SWAMPS-GLWD). In Africa, an even larger uncertainty in $\mathrm{CH}_{4}$ emission was found, ranging from $\sim 51.5 \mathrm{Tg} \mathrm{CH}_{4} \mathrm{yr}^{-1}$ (GLWD) to $\sim 15.5 \mathrm{Tg} \mathrm{CH}_{4} \mathrm{yr}^{-1}$ (GIEMS). In Asia, lower estimations were found using GISS (34.8 $\mathrm{Tg} \mathrm{CH}_{4} \mathrm{yr}^{-1}$ ), Kaplan (41.5 $\mathrm{Tg} \mathrm{CH}_{4} \mathrm{yr}^{-1}$ ) and SWAMPS-GLWD (42.3 $\mathrm{Tg} \mathrm{CH}_{4} \mathrm{yr}^{-1}$ ) data sets as input, while higher

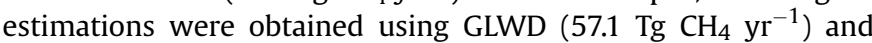
GIEMS (61.3 $\mathrm{Tg} \mathrm{CH}_{4} \mathrm{yr}^{-1}$ ) data sets. In North America, the highest estimation was obtained using GLWD $\left(\sim 51.1 \mathrm{Tg} \mathrm{CH}_{4} \mathrm{yr}^{-1}\right)$ data set, which was over three times higher than using GISS $\left(\sim 16.7 \mathrm{Tg} \mathrm{CH}_{4}\right.$ $\mathrm{yr}^{-1}$ ) data set. In contrast, in Europe, the highest estimation was derived using GISS ( $\left.11.6 \mathrm{Tg} \mathrm{CH}_{4} \mathrm{yr}^{-1}\right)$ data set, which was over two times higher than those using GLWD $\left(\sim 4.3 \mathrm{Tg} \mathrm{CH}_{4} \mathrm{yr}^{-1}\right)$ and Kaplan $\left(\sim 4.2 \mathrm{Tg} \mathrm{CH}_{4} \mathrm{yr}^{-1}\right)$ data set. In Oceania, $\mathrm{CH}_{4}$ emission was similar

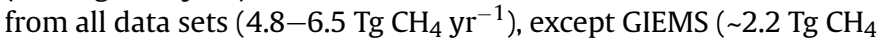
$\left.\mathrm{yr}^{-1}\right)$.

In general, we found that GLWD data set had larger wetland area in South America, Africa, Oceania, and North America than other data sets, and GIEMS data set had larger wetland area in Asia, while GISS data set had larger wetland area in Europe, which was roughly consistent with the model estimated divergence in $\mathrm{CH}_{4}$ emissions.

\subsection{Temporal variation in $\mathrm{CH}_{4}$ emissions}

Temporal patterns of $\mathrm{CH}_{4}$ emission were greatly different between the static and dynamic wetland data sets. The $\mathrm{CH}_{4}$ anomalies from all static wetland data sets (i.e., GISS, GLWD and Kaplan) showed similar inter-annual variations at all latitudinal bands since wetland extents were not changed with time and the inter-annual variations was mainly owing to the changing environmental factors.

The largest inter-annual variation in $\mathrm{CH}_{4}$ emissions occurred in the LL (Fig. 5). The $\mathrm{CH}_{4}$ emissions from the three static wetland data sets showed a significant increasing trend with a mean rate of $0.32 \mathrm{Tg} \mathrm{CH}_{4} \mathrm{yr}^{-1}$ during 1993-2005. On the contrary, the simulated $\mathrm{CH}_{4}$ fluxes using GIEMS demonstrated a significant decreasing trend with a rate of $0.92 \mathrm{Tg} \mathrm{CH}_{4} \mathrm{yr}^{-1}$ during 1993-2005. After 2007, the patterns of inter-annual variation in $\mathrm{CH}_{4}$ emissions were similar using GISS, GLWD, Kaplan, and SWAMPS-GLWD data sets, but with different magnitudes. For the ML, the simulation with GIEMS showed higher and positive $\mathrm{CH}_{4}$ emissions anomalies before 1997, opposite to that from other data sets. For the $\mathrm{HL}$, the simulated $\mathrm{CH}_{4}$ emission anomalies based on all data sets showed a reduction from 1993 to 1997, and followed by a small fluctuation during
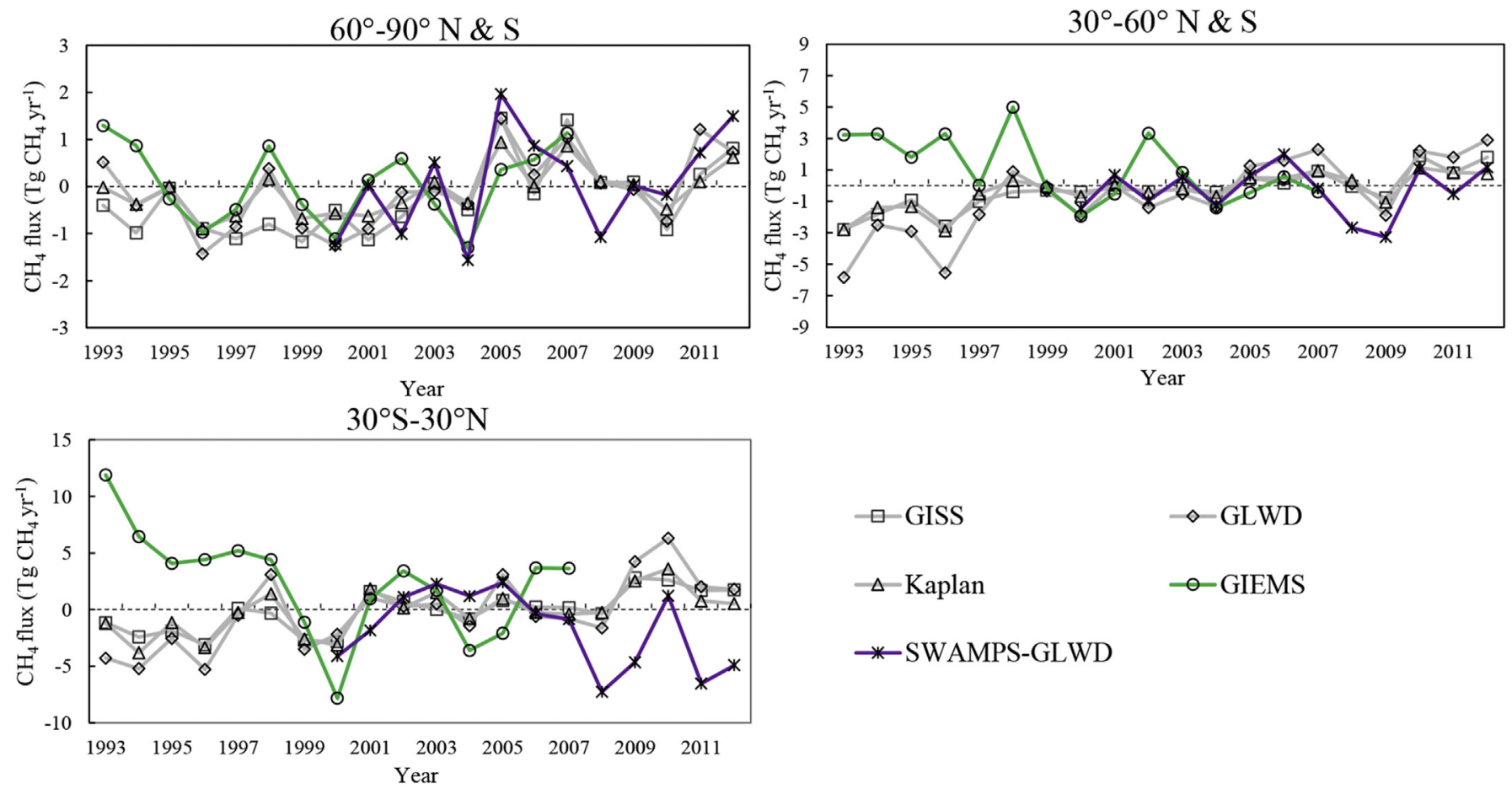

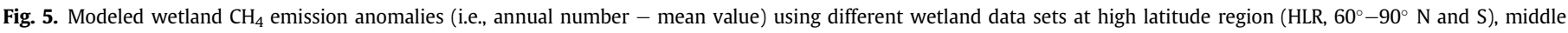
latitude region (MLR, $30^{\circ}-60^{\circ} \mathrm{N}$ and $\mathrm{S}$ ) and low latitude region (LLR, $30^{\circ} \mathrm{S}-30^{\circ} \mathrm{N}$ ). 
1998-2012, with the highest positive anomalies in 2005, 2007 and 2012.

The simulations with GLWD and SWAMPS-GLWD data sets showed the highest monthly $\mathrm{CH}_{4}$ emissions from global wetlands as compared to other data sets. Although the magnitudes were different, the estimated $\mathrm{CH}_{4}$ emissions using all data sets showed a similar intra-annual/seasonal variation (Fig. 6). Methane emissions decreased slightly from January to February, then increased and reached a peak in July and August and declined thereafter. Around $60 \%$ of annual emissions occurred during May-October.

\section{Discussion}

\subsection{The uncertainty source of wetland data sets}

There are large discrepancies in both the magnitude and spatial distributions of wetland extents among the five data sets used in this study (Zhu and Gong, 2014). This may be primarily due to the inconsistency in: 1) the definition and classification of wetland types, 2) the duration and time of the wetland data sets coverage, and 3 ) the purposes and methods of generating wetland data sets.

Three static wetland datasets (GISS, GLWD, Kaplan) defined and classified wetlands in distinct ways. Yet, the dynamic wetland datasets (GIEMS and SWAMPS-GLWD) were determined by the inundated fractions (Prigent et al., 2012). Static wetland data sets were unable to capture the seasonal variation over time, whereas around $60 \%$ of the wetlands were inundated only in a portion of the year (Prigent et al., 2016). In addition, GLWD has been argued to overestimate the wetland extent in arid or semiarid regions (Lehner and Döll, 2004; Melton et al., 2013) and in the northwest of WSL; however, it tended to underestimate the wetland area in the tundra region (Bohn et al., 2015). Still, GLWD was considered as the best choice to represent global wetland extent and types due to its high spatial resolution $(1 \mathrm{~km})$ and more detailed wetland categories (Prigent et al., 2016).

The wetland data sets were generated for different time periods (from early 1980s to early 2010s). Due to intensive human perturbations (e.g., wetland drainage and land conversion) and variations in climate (e.g., precipitation, temperature, soil freezing and thawing time), wetland extent could vary greatly year by year (Melton et al., 2013; Niu et al., 2012; Paudel et al., 2016; Prigent et al., 2016; Wei and Wang, 2016). For example, wetland has been drained for cultivation and decreased by 33\% in China during 1978-2008 (Niu et al., 2012; Wei and Wang, 2016); however, wetland area may not change dramatically in some other regions, such as the northern Alaska (Hall et al., 1994).
In general, there are three approaches towards generating the regional/global wetland extent data sets, including field investigations and statistical extrapolation, remote sensing monitoring, and model simulations. Field investigations and statistical extrapolation may reasonably capture the wetland extent for small regions, while still have challenges in mapping the fine-scale heterogeneity of wetland with high spatial/temporal resolution and large area coverage (Prigent et al., 2016; Terentieva et al., 2016). The wetland data sets from multi-satellite observations, considered the dynamic inundation extent at global scale, but cannot accurately represent the wetland without standing water (such as peatland) but with the water table beneath the land surface, some small wetlands with less than $10 \%$ fractional coverage of a grid cell, and the inundation area under dense forest canopy (Melton et al., 2013; Prigent et al., 2016; Terentieva et al., 2016). However, those areas could still produce considerable amounts of $\mathrm{CH}_{4}$. Thus, it is important to be cautious when using the dynamic wetland datasets in peatland-intensive area.

\subsection{Uncertainties in modeled $\mathrm{CH}_{4}$ emissions by using different wetland data sets}

The lack of consistence in wetland extent and distribution among different data sets caused the large uncertainty range in modeled $\mathrm{CH}_{4}$ emissions (Bohn et al., 2015; Bousquet et al., 2006; Ito and Inatomi, 2012; Melton et al., 2013; Wania et al., 2013). To determine the estimated $\mathrm{CH}_{4}$ emission per unit wetland area bias, we calculate the relative magnitude of the estimation uncertainties, which was defined as $\frac{F_{\mathrm{CH}_{4 i}}-F_{\mathrm{CH}_{4 m e a n}}}{\text { Area }_{i}-\text { Area }}$. Here i indicates different wetland data set. For the dynamic wetland data sets, the wetland area from GIEMS and SWAMPS-GLWD were determined by averaged annual maximum inundation extent, thus the higher estimation of wetland extent did not necessarily reflect the higher wetland extent throughout the year. But for the static wetland the relative magnitude of the uncertainties ranged from $5.9 \mathrm{~g} \mathrm{CH}_{4} \mathrm{~m}^{-2} \mathrm{yr}^{-1}$ (Kaplan) to $97.6 \mathrm{~g} \mathrm{CH}_{4} \mathrm{~m}^{-2} \mathrm{yr}^{-1}$ (GLWD). The higher bias of $\mathrm{CH}_{4}$ emission per unit wetland area from GLWD is owing to large wetland area distributed in the tropical and subtropical regions, where $\mathrm{CH}_{4}$ producing capability was markedly larger than other places. Despite only $14 \%$ coverage of global wetland, our study revealed that both South America and Africa, where averaged $\mathrm{CH}_{4}$ producing capabilities per unit wetland area are generally larger than other continents, contributes the greatest unknown in the global wetland $\mathrm{CH}_{4}$ budget.

Among a range of explanations, $\mathrm{CH}_{4}$ emission from wetlands has long been proposed as the dominant contributor to the recent

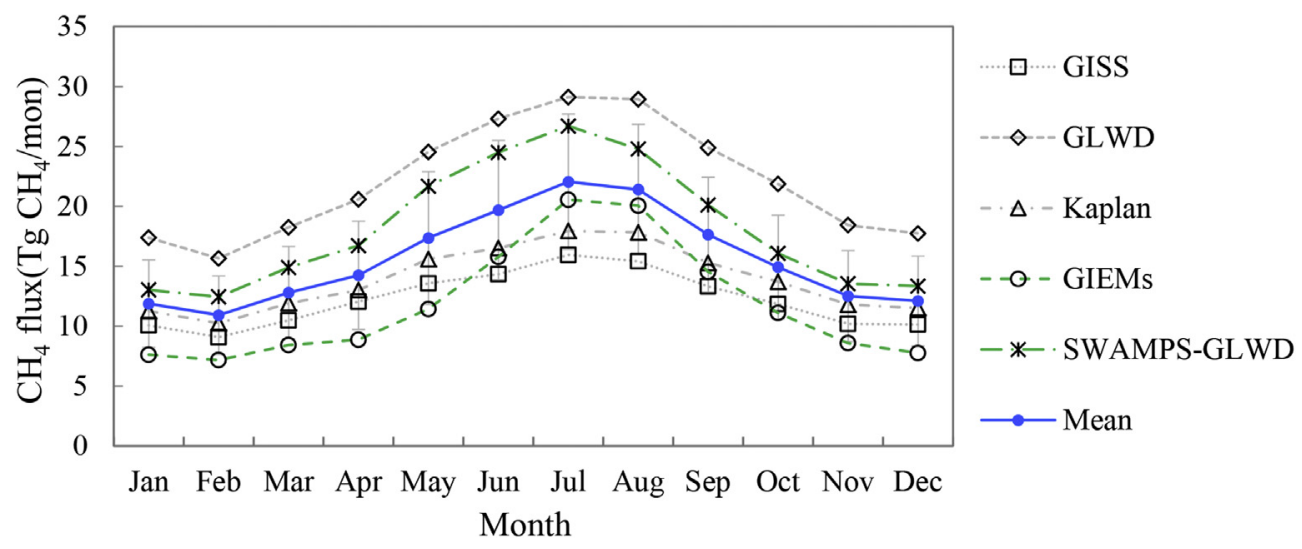

Fig. 6. Intra-annual variation of estimated wetland $\mathrm{CH}_{4}$ emission using different wetland data sets. 
variation of global $\mathrm{CH}_{4}$ burden. Our study also found a contrasting inter-annual variation pattern in $\mathrm{CH}_{4}$ fluxes between static wetland data sets and two dynamic wetland data sets. Thus, the ability of bottom-up approaches to estimate the inter-annual and intraannual variation of $\mathrm{CH}_{4}$ fluxes from the global wetlands relies on our understanding of the long-term dynamics of wetland extents and how different climatic factors could affect/control both temporal variation of wetland extents and the $\mathrm{CH}_{4}$ producing capabilities per unit area.

\subsection{Comparisons with other studies}

The selected wetland data sets in this study have been broadly used in many previous studies at both global and regional scales (Bohn et al., 2015; Ito and Inatomi, 2012; Matthews and Fung, 1987; Ringeval et al., 2010; Saunois et al., 2016; Wania et al., 2013). Unsurprisingly therefore, the estimated global wetland $\mathrm{CH}_{4}$ emission revealed a large range $\left(127.2 \pm 4.8-264 \pm 12 \mathrm{Tg} \mathrm{CH}_{4} \mathrm{yr}^{-1}\right)$ by using different data sets as inputs (Ito and Inatomi, 2012; Melton et al., 2013; Ringeval et al., 2011; Tian et al., 2015b; Wania et al., 2013), whereas our estimation was $177.2 \pm 49.7 \mathrm{Tg} \mathrm{CH}_{4} \mathrm{yr}^{-1}$. Analyzing the largest high-latitude wetland, Bohn et al. (2015) suggested that GISS and SWAMPS-GLWD underestimated the non-inundated peatland area, but overestimated the permanent wetland area by including water body due to the polluted signal from remotely sensed observations (Bohn et al., 2015; Prigent et al., 2012). On the other hand, for the second largest boreal wetland (HBL), the estimated $\mathrm{CH}_{4}$ emissions ranged from $2.2 \pm 0.2$ to $11.3 \pm 7.9 \mathrm{Tg} \mathrm{CH}_{4} \mathrm{yr}^{-1}$ using GIEMS data set (Melton et al., 2013), and our study suggested a similar estimation ranging from $1.9 \pm 0.1$ to $8.5 \pm 0.5 \mathrm{Tg} \mathrm{CH}_{4} \mathrm{yr}^{-1}$ in the HBL by using different data sets.

\subsection{Implication and future directions}

The results of this analysis compare the similarity and dissimilarity among existing wetland data sets and identify some common patterns among them, identify the regions/continents with the largest/least uncertainty in wetland extents and $\mathrm{CH}_{4}$ emissions, and bring forth some strategies for future development of more reliable wetland data sets for $\mathrm{CH}_{4}$ research. The information derived can be readily fed back to future researchers in particularly to select appropriate wetland data sets for their specific research objections and regions.

In theory, it should then be possible to capture the dynamic changes of wetland extent at global scale. But finding a way to do this still faces challenge nowadays. Several key characteristics of the future wetland data sets are desired: 1) shorter time step in delineating wetland extent and variations (from annual to monthly or even daily), 2) larger area coverage (from regional to continental and global), and 3) higher spatial resolution. Poor delineation of wetland extent and distribution has greatly affected the estimation accuracy of simulated $\mathrm{CH}_{4}$ fluxes. To reduce the present uncertainties and generate a more robust global wetland data set, future research efforts will need to integrate multiple sources of data from ground and satellite observations with multiple approaches (inventory, bottom-up and top-down modeling) for spatial and temporal extrapolation.

Future research could couple different existing data sets with some ongoing efforts (e.g., soil moisture monitoring from SMAPSoil Moisture Active Passive satellite) to improve the wetland extent in the regions we identified as poorly by current wetland data sets. GIEMS is a remote sensing product that primarily captures visible surface water while the Northern Circumpolar Soil Carbon Database (NCSCD) estimates peatland distribution (and peatlands may not have visible surface water) (Hugelius et al.,
2013). Coupling these two data sets with field observation could improve the estimation of peatland distribution meanwhile considering seasonal variation. High-resolution mapping of global surface water data sets, which provides surface water change at 30$\mathrm{m}$ resolution over the past 32 years (Pekel et al., 2016), together with SMAP, which provides the near real-time soil moisture data set with high spatial/temporal resolution, could use as a reference to examine the change in wetland extent.

Implication of multi-scale studies, such as extensive field investigation together with high resolution satellite images, could improve map accuracy from 56\% to 79\% (Terentieva et al., 2016). Thus, the identification of wetland areas at field or watershed scale could be used as ground truth data for training data and generate more accurate regional estimations (Terentieva et al., 2016).

In addition, the integration of multiple approaches is critical to bridge the knowledge gap, particularly for the regions that are poorly documented but with large amount of $\mathrm{CH}_{4}$ emission from a global perspective. The presence of wetlands could be inferred from satellite observation (e.g., SCIAMACHY- Scanning Imaging Absorption Spectrometer for Atmospheric Chartography), which identifies the hotspots with large $\mathrm{CH}_{4}$ emission, such as South America and Africa (Bergamaschi et al., 2007, 2009; Melton et al., 2013). However, large uncertainties of estimated $\mathrm{CH}_{4}$ emission in those regions were partially attributed to inconsistent wetland extent from different data sets, such as South America, where dense forest canopy coverage mingles the satellite (e.g., GIEMS and SWAMPSGLWD) signals for accurately detecting. It is urgent to collect more information about inter-annual and seasonal variation of wetland extent and $\mathrm{CH}_{4}$ emission at both site and regional scale in these identified regions with larger uncertainties. At present, several process-based models are applied to estimate wetland distribution within its model structure, such as SDGVM and UVicESCM (Melton et al., 2013). To improve the modeling accuracy of wetland extent, it is critical to improve the representation of hydrological processes and their regulations to $\mathrm{CH}_{4}$ fluxes, including more explicit representation of key hydrological processes, implementation of both horizontal and lateral water flows, and the incorporation of several important controls, such as freezing and thawing. These improvements from modeling group could contribute to reduce wetland data delineation-induced error. For example, the extant wetland data sets could not provide the information of wetland variation at finer scale, such as within-month or even daily, and model estimation provides primary characteristics of soil moisture at these time steps (Song et al., 2012). Thus, we need better model representation to understand and estimate dynamic hydrological cycles related to the changing wetland area. The integration of multiple approaches, such as inventory, bottom-up and top-down approaches could benefit from each other.

\section{Conclusion}

This study quantified the uncertainties in wetland area and distributions, as well as the estimated wetland $\mathrm{CH}_{4}$ emissions by using five widely used wetland data sets. There were extensive disagreements on the wetland distribution from the tropical to the northern high latitude region among five wetland data sets. The large uncertainty in wetland extents resulted in a large range of estimated $\mathrm{CH}_{4}$ emission from wetlands. The tropical regions contributed the largest portion of estimated $\mathrm{CH}_{4}$ emission from wetlands, but also have the largest discrepancy. Despite over half of the wetland located in the extra-tropical regions, improved understanding of both wetland extent and wetland $\mathrm{CH}_{4}$ emission in the tropical regions is essential to address the wetland's contribution to the $\mathrm{CH}_{4}$ budget in the context of global perspective. At continental scale, South America and Africa showed the largest 
uncertainty in the global wetland $\mathrm{CH}_{4}$ estimate because the actual wetland extent and temporal variations are uncertain.

Similar inter-annual variation of $\mathrm{CH}_{4}$ emissions was found in model simulations using the static wetland data sets, but it is significantly different from the model results using the dynamic wetland data sets. The large uncertainty range of estimated $\mathrm{CH}_{4}$ emission implies an urgent need to improve the accuracy of wetland extent data sets. Future wetland data sets with high temporal and spatial resolutions are desired. Considering the improved techniques and ongoing wetland monitoring activities, it is imperative to integrate multiple sources of data from ground and satellite observations with multiple approaches (inventory, bottom-up and top-down modeling) for spatial and temporal extrapolation.

\section{Acknowledgements}

This study has been supported by National Key Research and Development Program of China (No. 2017YFA0604700), the NASA Carbon System Monitoring Program (NNX12AP84G, NNX14AO73G), NSF Grants (1243232 and 1243220), CAS STS Program (KFJ-STS-ZDTP-010-05) and State Key Lab of Urban and Regional Ecology (SKLURE2017-1-6). We thank Dr. C. Prigent for providing the dynamic inundation extent data sets (GIEMS). All input data and output files are available from the corresponding author upon request (tianhan@auburn.edu).

\section{References}

Banger, K., Tian, H.Q., Zhang, B.W., Lu, C.Q., Ren, W., Tao, B., 2015. Biosphere-atmosphere exchange of methane in India as influenced by multiple environmental changes during 1901-2010. Atmos. Environ. 192-200.

Bergamaschi, P., Frankenberg, C., Meirink, J., Krol, M., Dentener, F., Wagner, T., Platt, U., Kaplan, J., Körner, S., Heimann, M., 2007. Satellite chartography of atmospheric methane from SCIAMACHY on board ENVISAT: 2. Evaluation based on inverse model simulations. J. Geophys. Res. Atmos. 112.

Bergamaschi, P., Frankenberg, C., Meirink, J.F., Krol, M., Villani, M.G., Houweling, S., Dentener, F., Dlugokencky, E.J., Miller, J.B., Gatti, L.V., 2009. Inverse modeling of global and regional $\mathrm{CH} 4$ emissions using SCIAMACHY satellite retrievals, J. Geophys. Res. Atmos. 114.

Bloom, A.A., Bowman, K.W., Lee, M., Turner, A.J., Schroeder, R., Worden, J.R., Weidner, R., McDonald, K.C., Jacob, D.J., 2017. A global wetland methane emissions and uncertainty dataset for atmospheric chemical transport models (WetCHARTs version 1.0). Geosci. Model Dev. 10, 2141-2156.

Bohn, T.J., Melton, J.R., Ito, A., Kleinen, T., Spahni, R., Stocker, B., Zhang, B., Zhu, X., Schroeder, R., Glagolev, M.V., Maksyutov, S., Brovkin, V., Chen, G., Denisov, S.N., Eliseev, A.V., Gallego-Sala, A., McDonald, K.C., Rawlins, M.A., Riley, W.J., Subin, Z.M., Tian, H.Q., Zhuang, Q., Kaplan, J.O., 2015. WETCHIMP-WSL: intercomparison of wetland methane emissions models over West Siberia. Biogeosciences 12, 3321-3349.

Bousquet, P., Ciais, P., Miller, J.B., Dlugokencky, E.J., Hauglustaine, D.A., Prigent, C., Van der Werf, G.R., Peylin, P., Brunke, E.G., Carouge, C., Langenfelds, R.L., Lathiere, J., Papa, F., Ramonet, M., Schmidt, M., Steele, L.P., Tyler, S.C., White, J., 2006. Contribution of anthropogenic and natural sources to atmospheric methane variability. Nature 443, 439-443.

Bridgham, S.D., Cadillo-Quiroz, H., Keller, J.K., Zhuang, Q.L., 2013. Methane emissions from wetlands: biogeochemical, microbial, and modeling perspectives from local to global scales. Glob. Change Biol. 19, 1325-1346.

Ciais, P., Sabine, C., Bala, G., Bopp, L., Brovkin, V., Canadell, J., Chhabra, A., DeFries, R., Galloway, J., Heimann, M., Jones, C., Le Quere, C., Myneni, R.B., Piao, S.L., Thornton, P., 2013. Carbon and other biogeochemical cycles. In: climate change 2013: the physical science basis. In: Stocker, T.F., Qin, D., Plattner, G.-K. Tignor, M., Allen, S.K., Boschung, J., Nauels, A., Xia, Y., Bex, V., Midgley, P.M. (Eds.), Contribution of Working Group I to the Fifth Assessment Report of the Intergovernmental Panel on Climate Change. Cambridge University Press, Cambridge, United Kingdom and New York, NY, USA, pp. 465-570.

Dentener, F., Drevet, J., Lamarque, J.F., Bey, I., Eickhout, B., Fiore, A.M., Hauglustaine, D., Horowitz, L.W., Krol, M., Kulshrestha, U.C., Lawrence, M., GalyLacaux, C., Rast, S., Shindell, D., Stevenson, D., Van Noije, T., Atherton, C., Bell, N., Bergman, D., Butler, T., Cofala, J., Collins, B., Doherty, R., Ellingsen, K. Galloway, J., Gauss, M., Montanaro, V., Müller, J.F., Pitari, G., Rodriguez, J., Sanderson, M., Solmon, F., Strahan, S., Schultz, M., Sudo, K., Szopa, S., Wild, O., 2006. Nitrogen and sulfur deposition on regional and global scales: a multimodel evaluation. Glob. Biogeochem. Cy 20, 1-21. http://dx.doi.org/10.1029/ 2005 GB002672.

Dlugokencky, E.J., Nisbet, E.G., Fisher, R., Lowry, D., 2011. Global atmospheric methane: budget, changes and dangers. Philos. T R. Soc. A 369, 2058-2072.

ETCTE, 2000. Corine Land Cover Database (Version 12/2000 Extended Coverage), the European Topic Centre on Terrestrial Environment. European Environment Agency.

FAO/IIASA/ISRIC/ISSCAS/JRC, 2012. Harmonized World Soil Database (Version 1.2). FAO, Rome, Italy and IIASA, Laxenburg, Austria.

Felzer, B., Reilly, J., Melillo, J., Kicklighter, D., Sarofim, M., Wang, C., Prinn, R., Zhuang, Q., 2005. Future effects of ozone on carbon sequestration and climate change policy using a global biogeochemical model. Clim. Change 73, 345-373.

Hall, V.J., Frayer, E.W., Wilen, O.B., 1994. Status of Alaska Wetlands. U. S. Fish and Wildlife Service Alaska Region.

Hugelius, G., Tarnocai, C., Broll, G., Canadell, J., Kuhry, P., Swanson, D., 2013. The Northern Circumpolar Soil Carbon Database: spatially distributed datasets of soil coverage and soil carbon storage in the northern permafrost regions. Earth Syst. Sci. Data $5,3-13$.

Ito, A., Inatomi, M., 2012. Use of a process-based model for assessing the methane budgets of global terrestrial ecosystems and evaluation of uncertainty. Biogeosciences 9, 759-773.

JRC, 2003. Global Land Cover 2000 Database. European Commission, Joint Research Centre, Ispra, Italy. http://www.gvm.jrc.it/glc2000.

Kaplan, J.O., 2007. A composite map of global wetland distribution at 0.5 degree resolution. Digital dataset available at: http://arve.epfl.ch/pub/wetlands/index. html. .

Kirschke, S., Bousquet, P., Ciais, P., Saunois, M., Canadell, J.G., Dlugokencky, E.J. Bergamaschi, P., Bergmann, D., Blake, D.R., Bruhwiler, L., Cameron-Smith, P., Castaldi, S., Chevallier, F., Feng, L., Fraser, A., Heimann, M., Hodson, E.L. Houweling, S., Josse, B., Fraser, P.J., Krummel, P.B., Lamarque, J.F., Langenfelds, R.L., Le Quere, C., Naik, V., O'Doherty, S., Palmer, P.I., Pison, I. Plummer, D., Poulter, B., Prinn, R.G., Rigby, M., Ringeval, B., Santini, M. Schmidt, M., Shindell, D.T., Simpson, I.J., Spahni, R., Steele, L.P., Strode, S.A., Sudo, K., Szopa, S., van der Werf, G.R., Voulgarakis, A., van Weele, M., Weiss, R.F. Williams, J.E., Zeng, G., 2013. Three decades of global methane sources and sinks. Nat. Geosci. 6, 813-823.

Klein Goldewijk, K., Beusen, A., van Drecht, G., de Vos, M., 2011. The HYDE 3.1 spatially explicit database of human-induced global land-use change over the past 12,000 years. Glob. Ecol. Biogeogr. 20, 73-86.

Lehner, B., Döll, P., 2004. Development and validation of a global database of lakes, reservoirs and wetlands. J. Hydrology 296, 1-22.

Lu, C.Q., Tian, H.Q., 2013. Net greenhouse gas balance in response to nitrogen enrichment: perspectives from a coupled biogeochemical model. Glob. Change Biol. 19, 571-588.

Matthews, E., Fung, I., 1987. Methane emission from natural wetlands: global distribution, area, and environmental characteristics of sources. Glob. Biogeochem. Cy 1, 61-86.

Melton, J.R., Wania, R., Hodson, E.L., Poulter, B., Ringeval, B., Spahni, R., Bohn, T. Avis, C.A., Beerling, D.J., Chen, G., Eliseev, A.V., Denisov, S.N., Hopcroft, P.O. Lettenmaier, D.P., Riley, W.J., Singarayer, J.S., Subin, Z.M., Tian, H., Zurcher, S. Brovkin, V., van Bodegom, P.M., Kleinen, T., Yu, Z.C., Kaplan, J.O., 2013. Present state of global wetland extent and wetland methane modelling: conclusions from a model inter-comparison project (WETCHIMP). Biogeosciences 10 753-788.

Mitsch, W.J., Bernal, B., Nahlik, A.M., Mander, Ü., Zhang, L., Anderson, C.J. Jørgensen, S.E., Brix, H., 2013. Wetlands, carbon, and climate change. Landsc Ecol. 28, 583-597.

Montzka, S.A., Dlugokencky, E.J., Butler, J.H., 2011. Non-CO2 greenhouse gases and climate change. Nature 476, 43-50.

Myhre, G., Shindell, D., Bréon, F.M., Collins, W., Fuglestvedt, J., Huang, J., Koch, D. Lamarque, J.F., Lee, D., Mendoza, B., Nakajima, Y., Robock, A., Stephens, G. Takemura, T., Zhang, H., 2013. Anthropogenic and natural radiative forcing. In: climate change 2013: the physical science basis. In: Stocker, T.F., Qin, D. Plattner, G.-K., Tignor, M., Allen, S.K., Boschung, J., Nauels, A., Xia, Y., Bex, V. Midgley, P.M. (Eds.), Contribution of Working Group I to the Fifth Assessment Report of the Intergovernmental Panel on Climate Change. Cambridge University Press, Cambridge, United Kingdom and New York, NY, USA, p. 423.

Niu, Z., Zhang, H., Wang, X., Yao, W., Zhou, D., Zhao, K., Zhao, H., Li, N., Huang, H., Li, C., 2012. Mapping wetland changes in China between 1978 and 2008. Chin. Sci. Bull. 57, 2813-2823.

Pan, S.F., Tian, H.Q., Dangal, S.R.S., Ouyang, Z.Y., Tao, B., Ren, W., Lu, C.Q., Running, S., 2014. Modeling and monitoring terrestrial primary production in a changing global environment: toward a multiscale synthesis of observation and simulation. Adv. Meteorology 2014, 1-17.

Pan, S.F., Tian, H.Q., Yang, Q.C., Yang, J., Lu, C.Q., Tao, B., Ren, W., Ouyang, Z.Y., 2015 Responses of global terrestrial evapotranspiration to climate change and increasing atmospheric CO2 in the 21st century. Earth's Future 3, 15-35.

Papa, F., Prigent, C., Aires, F., Jimenez, C., Rossow, W., Matthews, E., 2010. Interannual variability of surface water extent at the global scale, 1993-2004. J. Geophys. Res. Atmos. 115, D12111, 12110.11029/12009JD012674.

Paudel, R., Mahowald, N.M., Hess, P.G., Meng, L., Riley, W.J., 2016. Attribution of changes in global wetland methane emissions from pre-industrial to present using CLM4. 5-BGC. Environ. Res. Lett. 11, 034020.

Pekel, J.-F., Cottam, A., Gorelick, N., Belward, A.S., 2016. High-resolution mapping of global surface water and its long-term changes. Nature 540, 418-422.

Pison, I., Ringeval, B., Bousquet, P., Prigent, C., Papa, F., 2013. Stable atmospheric methane in the 2000s: key-role of emissions from natural wetlands. Atmos. Chem. Phys. 13, 11609-11623. 
Poulter, B., Bousquet, P., Canadell, J., Ciais, P., Peregon, A., Saunois, M., Arora, V., Beerling, D., Brovkin, V., Jones, C., Joos, F., Gedney, N., Ito, A., Kleinen, T., Koven, C., McDonald, K., Melton, J., Peng, C., Peng, S., Prigent, C., Schroder, R., Riley, W., Saito, M., Spahni, R., Tian, H., Taylor, L., Viovy, N., Wilton, D., Wiltshire, A., Xu, X., Zhang, B., Zhang, Z., Zhu, Q., 2017. Global wetland contribution to 2000-2012 atmospheric methane growth rate dynamics. Environ. Res. Lett. (submitted for publication).

Prigent, C., Lettenmaier, D.P., Aires, F., Papa, F., 2016. Toward a high-resolution monitoring of continental surface water extent and dynamics, at global scale: from GIEMS (Global Inundation Extent From Multi-Satellites) to SWOT (Surface Water Ocean Topography). Remote Sens. Water Resour. 149-165.

Prigent, C., Papa, F., Aires, F., Jimenez, C., Rossow, W.B., Matthews, E., 2012. Changes in land surface water dynamics since the 1990s and relation to population pressure. Geophys Res. Lett. 39, 1-5.

Ren, W., Tian, H.Q., Liu, M.L., Zhang, C., Chen, G.S., Pan, S.F., Felzer, B., Xu, X.F., 2007. Effects of tropospheric ozone pollution on net primary productivity and carbon storage in terrestrial ecosystems of China. J. Geophys Res-Atmos 112, 1-17.

Ren, W., Tian, H.Q., Xu, X.F., Liu, M.L., Lu, C.Q., Chen, G.S., Melillo, J., Reilly, J., Liu, J.Y., 2011. Spatial and temporal patterns of $\mathrm{CO} 2$ and $\mathrm{CH} 4$ fluxes in China's croplands in response to multifactor environmental changes. Tellus B 63, 222-240.

Ringeval, B., de Noblet-Ducoudré, N., Ciais, P., Bousquet, P., Prigent, C., Papa, F., Rossow, W.B., 2010. An attempt to quantify the impact of changes in wetland extent on methane emissions on the seasonal and interannual time scales. Glob. Biogeochem. Cy 24, 1-24.

Ringeval, B., Friedlingstein, P., Koven, C., Ciais, P., Noblet-Ducoudré, N.D., Decharme, B., Cadule, P., 2011. Climate-CH4 feedback from wetlands and its interaction with the climate-CO2 feedback. Biogeosciences 8, 2137-2157.

Saunois, M., Bousquet, P., Poulter, B., Peregon, A., Ciais, P., Canadell, J.G., Dlugokencky, E.J., Etiope, G., Bastviken, D., Houweling, S., JanssensMaenhout, G., Tubiello, F.N., Castaldi, S., Jackson, R.B., Alexe, M., Arora, V.K., Beerling, D.J., Bergamaschi, P., Blake, D.R., Brailsford, G., Brovkin, V., Bruhwiler, L., Crevoisier, C., Crill, P., Covey, K., Curry, C., Frankenberg, C., Gedney, N., Höglund-Isaksson, L., Ishizawa, M., Ito, A., Joos, F., Kim, H.S. Kleinen, T. Krummel, P. Lamarque, JF, Langenfelds, R., Locatelli, R, Machida, T, Maksyutov, S., McDonald, K.C., Marshall, J., Melton, J.R., Morino, I., Naik, V. O'Doherty, S., Parmentier, F.J.W., Patra, P.K., Peng, C., Peng, S., Peters, G.P., Pison, I., Prigent, C., Prinn, R., Ramonet, M., Riley, W.J., Saito, M., Santini, M., Schroeder, R., Simpson, I.J., Spahni, R., Steele, P., Takizawa, A., Thornton, B.F. Tian, H., Tohjima, Y., Viovy, N., Voulgarakis, A., van Weele, M., van der Werf, G.R. Weiss, R., Wiedinmyer, C., Wilton, D.J., Wiltshire, A., Worthy, D., Wunch, D. Xu, X., Yoshida, Y., Zhang, B., Zhang, Z., Zhu, Q., 2016. The global methane budget 2000-2012. Earth Syst. Sci. Data 8, 697-751.

Schroeder, R., McDonald, K.C., Chapman, B.D., Jensen, K., Podest, E., Tessler, Z.D. Bohn, T.J., Zimmermann, R., 2015. Development and evaluation of a multi-year fractional surface water data set derived from active/passive microwave remote sensing data. Remote Sens. 7, 16688-16732.

Song, C., Xu, X., Sun, X., Tian, H., Sun, L., Miao, Y., Wang, X., Guo, Y., 2012. Large methane emission upon spring thaw from natural wetlands in the northern permafrost region. Environ. Res. Lett. 7, 034009.

Spahni, R., Wania, R., Neef, L., van Weele, M., Pison, I., Bousquet, P., Frankenberg, C. Foster, P.N., Joos, F., Prentice, I.C., van Velthoven, P., 2011. Constraining globa methane emissions and uptake by ecosystems. Biogeosciences 8, 1643-1665.

Stacke, T., Hagemann, S., 2012. Development and validation of a global dynamical wetlands extent scheme. Hydrology Earth Syst. Sci. 16, 2915-2933.

Tarnocai, C., Kettles, I.M., Lacelle, B., 2000. Peatlands of Canada Database. Geological Survey of Canada Open File Report 3834.

Terentieva, I.E., Glagolev, M.V., Lapshina, E.D., Sabrekov, A.F., Maksyutov, S., 2016 Mapping of West Siberian taiga wetland complexes using Landsat imagery: implications for methane emissions. Biogeosciences 13, 4615-4626.

Tian, H., Lu, C., Ciais, P., Michalak, A.M., Canadell, J.G., Saikawa, E., Huntzinger, D.N., Gurney, K.R., Sitch, S., Zhang, B., Yang, J., Bousquet, P., Bruhwiler, L., Chen, G. Dlugokencky, E., Friedlingstein, P., Melillo, J., Pan, S., Poulter, B., Prinn, R., Saunois, M., Schwalm, C.R., Wofsy, S.C., 2016. The terrestrial biosphere as a net source of greenhouse gases to the atmosphere. Nature 531, 225-228.

Tian, H., Lu, C., Yang, J., Banger, K., Huntzinger, D.N., Schwalm, C.R., Michalak, A.M., Cook, R., Ciais, P., Hayes, D., Huang, M., Ito, A., Jain, A.K., Lei, H., Mao, J., Pan, S. Post, W.M., Peng, S., Poulter, B., Ren, W., Ricciuto, D., Schaefer, K., Shi, X., Tao, B.,
Wang, W., Wei, Y., Yang, Q., Zhang, B., Zeng, N., 2015a. Global patterns and controls of soil organic carbon dynamics as simulated by multiple terrestrial biosphere models: current status and future directions. Glob. Biogeochem. Cy 29, 775-792.

Tian, H.Q., Chen, G.S., Liu, M.L., Zhang, C., Sun, G., Lu, C.Q., Xu, X.F., Ren, W., Pan, S.F., Chappelka, A., 2010a. Model estimates of net primary productivity, evapotranspiration, and water use efficiency in the terrestrial ecosystems of the southern United States during 1895-2007. For. Ecol. Manag. 259, 1311-1327.

Tian, H.Q., Chen, G.S., Lu, C.O. Xu, X.F., Ren, W., Zhang, B.W., Banger, K., Tao, B. Pan, S.F., Liu, M.L., Zhang, C., Bruhwiler, L., Wofsy, S.C., 2015b. Global methane and nitrous oxide emissions from terrestrial ecosystems due to multiple environmental changes. Ecosyst. Health Sustain. 1, 1-20.

Tian, H.Q., Lu, C.Q., Melillo, J., Ren, W., Huang, Y., Xu, X.F., Liu, M.L., Zhang, C., Chen, G.S., Pan, S.F., Liu, J.Y., Reilly, J., 2012. Food benefit and climate warming potential of nitrogen fertilizer uses in China. Environ. Res. Lett. 7, 044020.

Tian, H.O., Xu, X.F., Liu, M.L., Ren, W., Zhang, C., Chen, G.S., Lu, C.O., 2010b. Spatial and temporal patterns of $\mathrm{CH} 4$ and $\mathrm{N} 2 \mathrm{O}$ fluxes in terrestrial ecosystems of North America during 1979-2008: application of a global biogeochemistry model. Biogeosciences 7, 2673-2694.

Tian, H.Q Xu, X.F, Lu, C.O, Liu, M.L, Ren, W. Chen, G.S, Melillo, J., Liu, J.Y, 2011. Net exchanges of $\mathrm{CO} 2, \mathrm{CH} 4$, and $\mathrm{N} 2 \mathrm{O}$ between China's terrestrial ecosystems and the atmosphere and their contributions to global climate warming. J. Geophys Res-Biogeo 116, 1-13.

Tian, H.Q., Yang, Q.C., Najjar, R.G., Ren, W., Friedrichs, M.A.M., Hopkinson, C.S., Pan, S.F., 2015c. Anthropogenic and climatic influences on carbon fluxes from eastern North America to the Atlantic Ocean: a process-based modeling study. J. Geophys. Res. Biogeosciences 120, 757-772.

Vogelmann, J.E., Howard, S.M., Yang, L., Larson, C.R., Wylie, B.K., Van Driel, N., 2001. Completion of the 1990s national land cover data set for the conterminous United States from landsat thematic mapper data and ancillary data sources. Photogrammetric Eng. Remote Sens. 67, 650-652.

Wania, R., Melton, J.R., Hodson, E.L., Poulter, B., Ringeval, B., Spahni, R., Bohn, T., Avis, C.A., Chen, G., Eliseev, A.V., Hopcroft, P.O., Riley, W.J., Subin, Z.M., Tian, H., van Bodegom, P.M., Kleinen, T., Yu, Z.C., Singarayer, J.S., Zürcher, S., Lettenmaier, D.P., Beerling, D.J., Denisov, S.N., Prigent, C., Papa, F., Kaplan, J.O., 2013. Present state of global wetland extent and wetland methane modelling: methodology of a model inter-comparison project (WETCHIMP). Geosci. Model Dev. 6, 617-641.

Wei, D., Wang, X., 2016. CH4 exchanges of the natural ecosystems in China during the past three decades: the role of wetland extent and its dynamics. J. Geophys. Res. Biogeosciences 121, 2445-2463.

Wei, Y., Liu, S., Huntzinger, D.N., Michalak, A.M., Viovy, N., Post, W.M., Schwalm, C.R., Schaefer, K., Jacobson, A.R., Lu, C., Tian, H., Ricciuto, D.M., Cook, R.B., Mao, J. Shi, X., 2014. the North american carbon Program multi-scale synthesis and terrestrial model intercomparison project - Part 2: environmental driver data. Geosci. Model Dev. 7, 2875-2893.

WMO, 2015. World meteorological organization greenhouse gas bulletin. Citeseer. ISSN: 2071-0896.

Xu, X.F., Tian, H.Q., 2012. Methane exchange between marshland and the atmosphere over China during 1949-2008. Glob. Biogeochem. Cy 26.

Xu, X.F., Tian, H.Q., Zhang, C., Liu, M.L., Ren, W., Chen, G.S., Lu, C.Q., Bruhwiler, L., 2010. Attribution of spatial and temporal variations in terrestrial methane flux over North America. Biogeosciences 7, 3637-3655.

Zhang, B., Tian, H., Ren, W., Tao, B., Lu, C., Yang, J., Banger, K., Pan, S., 2016. Methane emissions from global rice fields: magnitude, spatiotemporal patterns, and environmental controls. Glob. Biogeochem. Cy 30, 1246-1263.

Zhu, P., Gong, P., 2014. Suitability mapping of global wetland areas and validation with remotely sensed data. Sci. China Earth Sci. 57, 2283-2292.

Zhu, Q., Peng, C., Chen, H., Fang, X., Liu, J., Jiang, H., Yang, Y., Yang, G., 2015. Estimating global natural wetland methane emissions using process modelling: spatio-temporal patterns and contributions to atmospheric methane fluctuations. Glob. Ecol. Biogeogr. 24, 959-972.

Zhuang, Q., Zhu, X., He, Y., Prigent, C., Melillo, J.M., McGuire, A.D., Prinn, R.G., Kicklighter, D.W., 2015. Influence of changes in wetland inundation extent on net fluxes of carbon dioxide and methane in northern high latitudes from 1993 to 2004. Environ. Res. Lett. 10, 095009. 